Wolfgang Blenau | Frank Hauser | Guiseppe Cazzamali | Michael Williamson | Cornelis J. P. Grimmelikhuijzen

\title{
A review of neurohormone GPCRs present in the fruitfly Drosophila melanogaster and the honey bee Apis mellifera
}

Suggested citation referring to the original publication:

Progress in neurobiology 80 (2006) 1, S. 1-19

DOI https://doi.org/10.1016/j.pneurobio.2006.07.005

ISSN 0301-0082 



\title{
Neurobiology
}

Progress in Neurobiology 80 (2006) 1-19

www.elsevier.com/locate/pneurobio

\section{A review of neurohormone GPCRs present in the fruitfly Drosophila melanogaster and the honey bee Apis mellifera ${ }^{\text {is }}$}

\author{
Frank Hauser ${ }^{a}$, Giuseppe Cazzamali ${ }^{a}$, Michael Williamson ${ }^{a}$, \\ Wolfgang Blenau ${ }^{\mathrm{b}}$, Cornelis J.P. Grimmelikhuijzen ${ }^{\mathrm{a}, *}$ \\ ${ }^{a}$ Center for Functional and Comparative Insect Genomics and Department of Cell Biology and Comparative Zoology, \\ Institute of Biology, University of Copenhagen, Universitetsparken 15, DK-2100 Copenhagen, Denmark \\ ${ }^{\mathrm{b}}$ Department of Animal Physiology, Institute of Biochemistry and Biology, University of Potsdam, \\ Karl-Liebknecht-Strasse 24, D-14471 Potsdam, Germany
}

Received 12 May 2006; received in revised form 17 July 2006; accepted 17 July 2006

\begin{abstract}
G protein-coupled receptor (GPCR) genes are large gene families in every animal, sometimes making up to 1-2\% of the animal's genome. Of all insect GPCRs, the neurohormone (neuropeptide, protein hormone, biogenic amine) GPCRs are especially important, because they, together with their ligands, occupy a high hierarchic position in the physiology of insects and steer crucial processes such as development, reproduction, and behavior. In this paper, we give a review of our current knowledge on Drosophila melanogaster GPCRs and use this information to annotate the neurohormone GPCR genes present in the recently sequenced genome from the honey bee Apis mellifera. We found 35 neuropeptide receptor genes in the honey bee (44 in Drosophila) and two genes, coding for leucine-rich repeats-containing protein hormone GPCRs (4 in Drosophila). In addition, the honey bee has 19 biogenic amine receptor genes (21 in Drosophila). The larger numbers of neurohormone receptors in Drosophila are probably due to gene duplications that occurred during recent evolution of the fly. Our analyses also yielded the likely ligands for 40 of the 56 honey bee neurohormone GPCRs identified in this study. In addition, we made some interesting observations on neurohormone GPCR evolution and the evolution and co-evolution of their ligands. For neuropeptide and protein hormone GPCRs, there appears to be a general co-evolution between receptors and their ligands. This is in contrast to biogenic amine GPCRs, where evolutionarily unrelated GPCRs often bind to the same biogenic amine, suggesting frequent ligand exchanges ("ligand hops") during GPCR evolution.
\end{abstract}

(C) 2006 Elsevier Ltd. All rights reserved.

Keywords: GPCR; Neuropeptide; Neurohormone; Hormone; Biogenic amine; Genomics; Insect; Honey bee; Drosophila

\section{Contents}

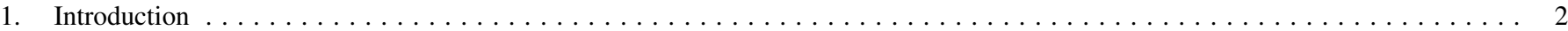

2. Neurohormone receptor genes present in the fruitfly and honey bee genomes $\ldots \ldots \ldots \ldots$

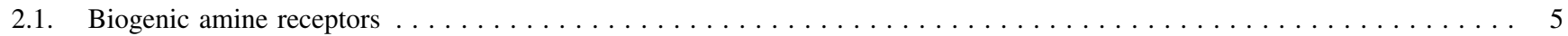

2.1.1. Honey bee biogenic amine receptor genes that have been previously deorphanized $\ldots \ldots \ldots$

\footnotetext{
Abbreviations: AKH, adipokinetic hormone; CCAP, crustacean cardioactive peptide; $\mathrm{CHO}$, Chinese hamster ovary; $\mathrm{CRF}$, corticotropin releasing factor; DH, diuretic hormone; DLGR, Drosophila leucine-rich repeats-containing GPCR; ETH, ecdysis triggering hormone; GFP, green fluorescent protein; GPCR, G proteincoupled receptor; ic3, intracellular loop 3; LGR, leucine-rich repeats-containing GPCR; LRR, leucine-rich repeat; mACHR, muscarinic acetylcholine receptor; MIP, myoinhibitory peptide; NPF, neuropeptide F; PDF, pigment dispersing factor; PLC, phospholipase C; sNPF, short neuropeptide F; 7TM, seven transmembrane

Nucleotide sequence data reported here are available in the CoreNucleotide or third party annotation section of the DDBJ/EMBL/GenBank databases under the accession numbers: AF498306; AJ245824; AJ547798; AY921573; AY_961388-AY_961391; AY_961393-AY_961396; BK005219; BK005220; BK005238BK005242; BK005257-BK005259; BK005261-BK005269; BK005271; BK005273; BK005274; BK005684; BK005712; BK005714-BK005719; BK005754; DQ151547; DQ201783; XP_394102; XP_394798; XP_395101; XP_395760; XP_396348; XP_396445; XP_396491; XP_397077; Y13429.

* Corresponding author at: Department of Cell Biology and Comparative Zoology, Universitetsparken 15, DK-2100 Copenhagen, Denmark. Tel.: +45 3532 1227; fax: +4535321220 .

E-mail address: cgrimmelikhuijzen@bi.ku.dk (C.J.P. Grimmelikhuijzen).
} 
2.1.2. Orphan honey bee biogenic amine receptor genes that have a deorphanized Drosophila orthologue . . . . . . . 6

2.1.3. Honey bee biogenic amine receptor genes that have an orphan Drosophila orthologue . . . . . . . . . . 7

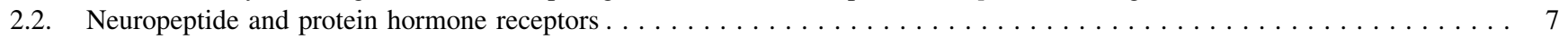

2.2.1. Honey bee neuropeptide and protein hormone receptor genes that have a "deorphanized" Drosophila orthologue . . . 7

2.2.2. Honey bee neuropeptide and protein hormone receptor genes that have an "orphan" Drosophila orthologue . . . 14

2.2.3. Honey bee neuropeptide and protein hormone receptor genes that do not have a clear Drosophila orthologue. . . 14

2.2.4. Drosophila neuropeptide and protein hormone receptor genes that do not have a honey bee orthologue . . . . . 14

2.2.5. Neuropeptide and protein hormone receptor paralogues that are present in Drosophila, but that are absent in

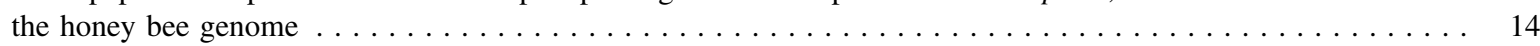

2.2.6. Neuropeptide and protein hormone receptor paralogues that are present in the honey bee, but absent in Drosophila. . . 15

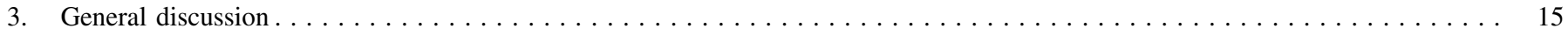

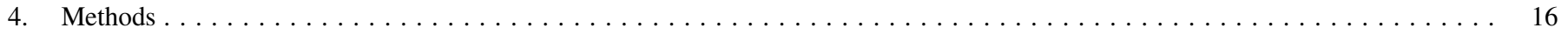

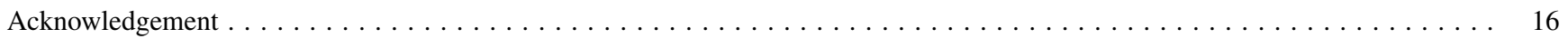

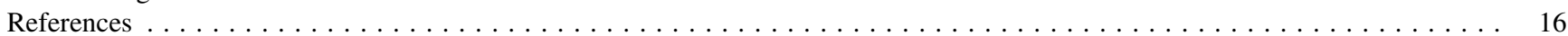

\section{Introduction}

Insects are the largest animal group in the world ( $75 \%$ of all species are insects) and are economically and ecologically extremely important, because most flowering plants depend on insects for their pollination. The honey bees alone, for example, pollinate 20 billion dollars worth of crop yearly in the United States. But insects can also be severe agricultural pests, destroying $30 \%$ of our potential annual harvest, and can be vectors (intermediate pathogen carriers) for major diseases such as malaria, sleeping sickness, dengue fever, yellow fever, and elephantiasis.

There are, at present, highly exciting developments occurring within the field of insect research, because the genomes from the fruitfly Drosophila melanogaster and the malaria mosquito Anopheles gambiae (both belonging to the insect order Diptera, or flies) and that from the silkworm Bombyx mori (belonging to the order Lepidoptera, or moths and butterflies) have recently been sequenced (Adams et al., 2000; Holt et al., 2002; Xia et al., 2004). The latest published addition to insect genomics is the completion of the Honey Bee Genome Project (The Honey Bee Genome Sequencing Consortium, 2006).

Insects can be subdivided into two evolutionary lineages, the Holometabola (insects with a complete metamorphosis during development) and Hemimetabola (insects with an incomplete metamorphosis). The genomic sequences from the honey bee are especially exciting, because the honey bee belongs to an insect order (the Hymenoptera), which has very recently been shown to occupy the most basal position in the Holometabola lineage (Savard et al., 2006). In contrast, the Diptera are the most advanced holometabolous insects. A comparison between the two insect orders, as we do in the current review, therefore, will give us invaluable evolutionary information on holometabolous insects, which comprise $80-85 \%$ of all insect species. For the study of the evolution of insects it would, of course, be even more interesting to compare the genomes from holometabolous with that from hemimetabolous insects. Unfortunately, large-scale genomic information on hemimetabolous insects is not available yet.

The honey bee is extremely important for agriculture as a major pollinator and as a producer of honey. Furthermore, the honey bee is a well-studied social insect, which has fascinating social instincts and behavioral traits that involve learning, communication, and navigation. The honey bees even have their own language known as the honey bee dance (the only known non-primate symbolic language) and research in this area has been awarded with a Nobel Prize to Karl von Frisch in 1973 (von Frisch, 1994). It is expected that the sequencing of the honey bee genome will advance our knowledge of this insect enormously, which will have a strong impact on both the applied part of honey bee research (related to agriculture) and the more basic research on social behavior and learning of the bee. Moreover, all new results obtained in the honey bee will be highly relevant for our studies of other social insects, such as ants, wasps, and termites.

$\mathrm{G}$ protein-coupled receptor (GPCR) genes are large gene families in all animals, sometimes making up 1-2\% of the animals' genome. Also in the honey bee genome, a large number (about 240) of GPCR genes have been identified, which is about $1.5 \%$ of the total number of genes present in the bee (The Honey Bee Sequencing Consortium, 2006). GPCRs are transmembrane proteins with a characteristic topology, consisting of an extracellular $\mathrm{N}$ terminus, seven hydrophobic transmembrane $\alpha$ helices and an intracellular $\mathrm{C}$ terminus. GPCRs are activated by extracellular signals, after which they initiate a second messenger cascade in the interior of the cell, thus transducing the signals from the outside to the inside of the cell. GPCRs can be receptors for light (the rhodopsins), odorants (olfactory receptors), or neurotransmitters/neurohormones. They can be classified into four families: rhodopsin-like (or family A), secretin receptor-like (family B), metabotropic glutamate receptor-like (family $\mathrm{C}$ ), and atypical receptors (family D). All families have the same seven transmembrane topology, but differ by amino acid residues at certain characteristic positions. For example, family A receptors have a conserved Asp-Arg-Tyr (DRY) sequence motif just after the third transmembrane $\alpha$ helix, whereas this motif is lacking in members of the other GPCR families (Gether, 2000).

Our research group is especially interested in neurohormone GPCRs from insects and their corresponding ligands (the neuropeptides, protein hormones, and biogenic amines), because these molecules play a central role in the physiology of these animals, i.e., they occupy a high "hierarchic" position 
in the steering or coordination of important processes, such as reproduction, development, growth, feeding, homeostasis, and behavior. Because the Drosophila Genome Project was the first insect genome project to be completed (Adams et al., 2000), most information on insect neurohormone GPCRs is available from Drosophila. The website of the Drosophila Genome Project contains a list of 41 genes predicted ("annotated") to code for neuropeptide GPCRs, three for protein hormone GPCRs, and 21 for biogenic amine GPCRs (Hewes and Taghert, 2001) (www.flybase.org). We found one additional protein hormone GPCR and three neuropeptide GPCRs that were not annotated by flybase, thus the total number of neurohormone GPCRs in Drosophila is probably 69 (Hauser et al., 2006). We have further found, after cDNA cloning, that in many cases the flybase annotations were incorrect, because the predicted intron/exon organizations were wrong, or because exons from other annotated neighboring genes also were part of the correct receptor gene. Furthermore, the ligands for many of the annotated receptor genes are unknown, i.e., they are orphan receptors. Therefore, proper cDNA cloning of the annotated receptor genes and subsequent ligand identification are still necessary processes.

There are several ways to identify a ligand for an orphan receptor. They all imply the heterologous expression of the receptor cDNA in cells, which, for example, can be frog oocytes, or mammalian cells in cell culture. The activation of the expressed GPCRs by a tissue extract, containing the ligand, or by a synthetic ligand from a chemical library can be measured by the second messenger responses (for example, by changes in cytoplasmic cAMP or $\mathrm{Ca}^{2+}$ concentrations in mammalian cells, or cAMP- or $\mathrm{Ca}^{2+}$-induced ion currents across the cell membranes of frog oocytes). When a second messenger response occurs, the cells can be used as a bioassay and the ligand can be purified and identified (in the case of an extract) or directly be determined if the ligand comes from a library (Civelli et al., 2001; Civelli, 2005). We and others have been especially successful with a system, where we have stably transfected Chinese hamster ovary (CHO) cells in cell culture with a cDNA for an insect GPCR. These cells were also stably transfected with DNA, coding for the promiscuous $\mathrm{G}$ protein, G-16, and transiently transfected with DNA, coding for apoaequorin. Three hours before the assay, we added the co-factor of apoaequorin, coelenterazine, to the culture medium. An activation of the expressed receptor in such pretreated cells would initiate an $\mathrm{IP}_{3} /$ $\mathrm{Ca}^{2+}$ cascade, leading to a strong bioluminescence response (Stables et al., 1997; Lenz et al., 2001; Secher et al., 2001; Staubli et al., 2002; Cazzamali and Grimmelikhuijzen, 2002; Meeusen et al., 2002; Mertens et al., 2002). A schematic drawing of this bioassay is given in Fig. 1. The system can be improved by selecting cell clones that express the GPCRs most effectively. This can be done by using a transfection vector that, in addition to DNA coding for the insect GPCR, also contains DNA coding for green fluorescent protein (GFP). In this case, the cell clones with strongest fluorescence can be selected and used in our assay system. An example of such an assay in cloned cell lines is given in Fig. 2, where the insect neuropeptide proctolin (RYLPT) induces a bioluminescence response in $\mathrm{CHO}$ cells expressing the proctolin receptor, which is $400 \times$ over background. These are robust responses that give clear answers as to the identity of the ligands for the insect orphan GPCRs.

In the last few years, our group and others have successfully cloned and identified ("deorphanized") about 40 Drosophila neurohormone GPCRs, or more than half of all neurohormone GPCRs that are believed to be present in the fruitfly. This work has already given us impressive insights not only into the neuroendocrinology of Drosophila but also into the evolution of neurohormone receptors and co-evolution of the receptors and their ligands (Park et al., 2002; Rosenkilde et al., 2003; Mendive et al., 2005). All this knowledge gained in Drosophila can be used to understand the molecular endocrinology of other insects, and the first insect groups where this knowledge can be applied will, of course, be those groups for which a genome project exists.

Neurohormone receptors and their ligands are expected to play a central role in the learning and behavior of the honey bee. The releases of genomic sequencing data (December 2003Spring 2006) prior to the current publication of the honey bee genome (The Honey Bee Sequencing Consortium, 2006), therefore, immediately raised the question about the presence of these molecules in the bee. For these reasons, we started an annotation project for neurohormone receptors right after the first genomic sequences from the honey bee were released (December 2003). In the present paper, we will describe the results of this annotation effort, where we discovered 51 novel honey bee neurohormone GPCRs in addition to five biogenic amine GPCRs characterized earlier. We will also review our current knowledge on Drosophila neurohormone GPCRs and describe the evolution of insect GPCRs based on our analyses of the two insect species.

\section{Neurohormone receptor genes present in the fruitfly and honey bee genomes}

We used the amino acid sequences of both the annotated and the identified (cloned and "deorphanized") Drosophila neurohormone receptors (www.flybase.org; Hewes and Taghert, 2001; Hauser et al., 2006) to screen (BLAST search) the genomic sequences released by the Honey Bee Genome Project (www.hgsc.bcm.edu/projects/honeybee/). We started our manual annotations right after the first release of the honey bee genomic sequences in December 2003 (Amel_1.0), where we already could assign most of the neurohormone receptor genes present in the honey bee, and finished with the release of March 2006 (Amel_4.0). Version Amel_2.0 (January 2005) was analyzed by several gene finding programs, the latest one being Glean3 (The Honey Bee Sequencing Consortium, 2006). We have manually curated all GPCR genes predicted by the Glean3 program and in many cases found additional sequences. We have also found several GPCR genes that were not predicted by Glean3. In addition, we compared the honey bee neurohormone GPCRs with those from Drosophila, using phylogenetic tree (Figs. 3-5) and gene structure (Tables 1 and 2) analyses. These combined analyses resulted in the annotation of 19 biogenic amine GPCR genes (for reasons of convenience, numbered Am 1-19 from top to bottom in Fig. 3), 35 neuropeptide receptor 


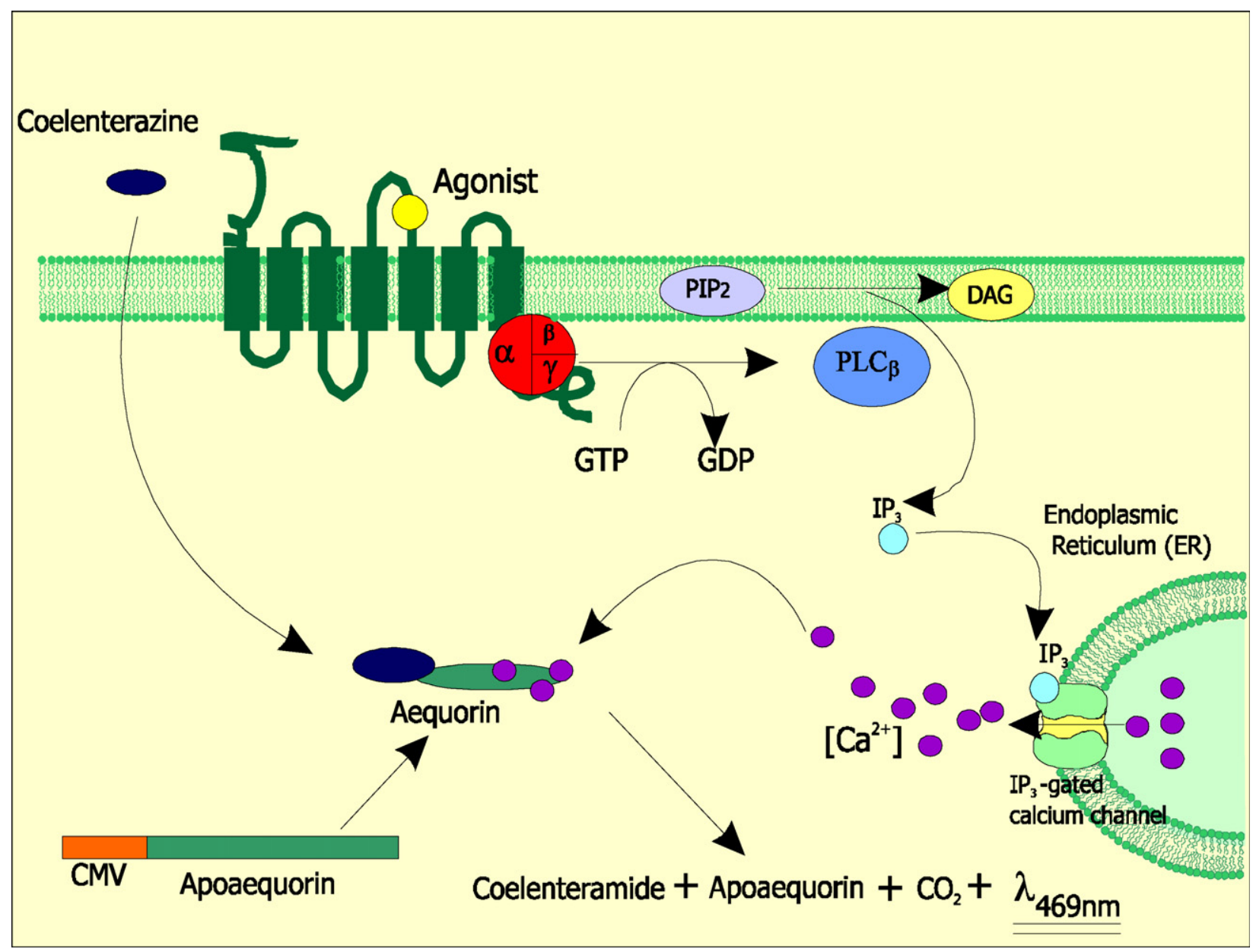

Fig. 1. Schematic drawing of the assay system used in our research group. In the upper part the CHO cell membrane is shown, expressing the insect GPCR (dark green), which binds to both the extracellular agonist (yellow) and the intracellular G protein, G-16 (red). Upon receptor activation, the $\alpha$ subunit of G-16 dissociates from the $\beta / \gamma$ subunits and activates phospholipase $\mathrm{C}\left(\mathrm{PLC}_{\beta}\right)$ which initiates an $\mathrm{IP}_{3} / \mathrm{Ca}^{2+}$ cascade. The increased $\mathrm{Ca}^{2+}$ concentration stimulates aequorin to emit light of $469 \mathrm{~nm}$ (bioluminescence). This system was first published by Stables and coworkers for mammalian GPCRs (1997) and successfully modified and applied by us for GPCRs from insects (Staubli et al., 2002). For further details, see text.

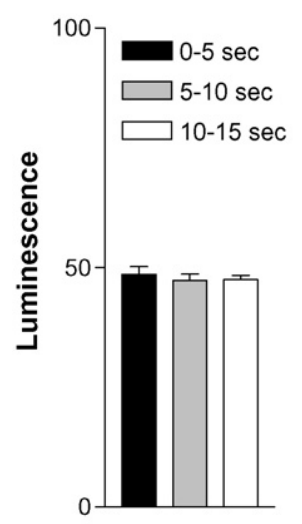

(A)

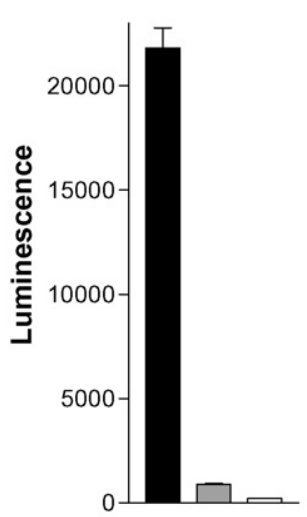

(B)

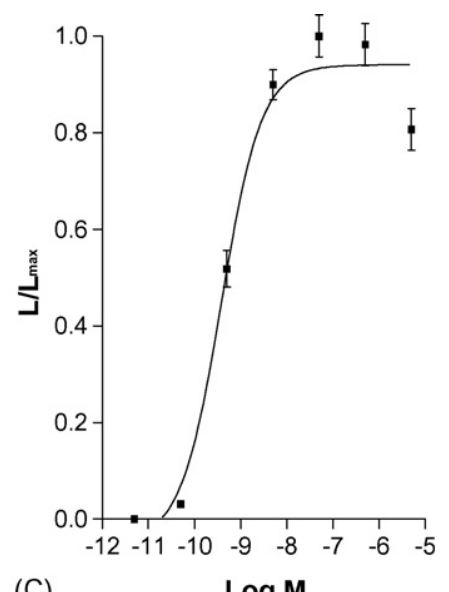

(C)

\section{$\log M$}

Fig. 2. An example of the experimental outcome of a bioassay schematically described in Fig. 1. The CHO cells were transfected with DNA, coding for the Drosophila proctolin (RYLPT) receptor (Egerod et al., 2003b). From the stably transfected cell pool, a cell line was selected that expressed the proctolin receptor most efficiently (see text). The vertical bars represent SEM, which sometimes are smaller than the symbols (or lines) used. In these cases, only the symbols (or lines) are given. (A) A control, where phosphate buffered saline (PBS) was added to the transfected cells. The cells did not react and had a background of 50 luminescence units. (B) Luminescence responses when $5 \times 10^{-7} \mathrm{M}$ proctolin was added to the transfected cells. There is a strong response within $5 \mathrm{~s}$ of over 20,000 luminescence units, which is more than $400 \times$ over background. Furthermore, there is a clear desensitization 10-15 s after addition of the peptide. Note that the scale of the $Y$-axis is different from that in (A). (C) Dose-response curve of the effects seen in (B). The curve shows an $\mathrm{EC}_{50}$ of $6 \times 10^{-10} \mathrm{M}$. Above $10^{-7} \mathrm{M}$, the response decreases, because of desensitization that occurs within $5 \mathrm{~s}$ after addition of high concentrations of proctolin. 


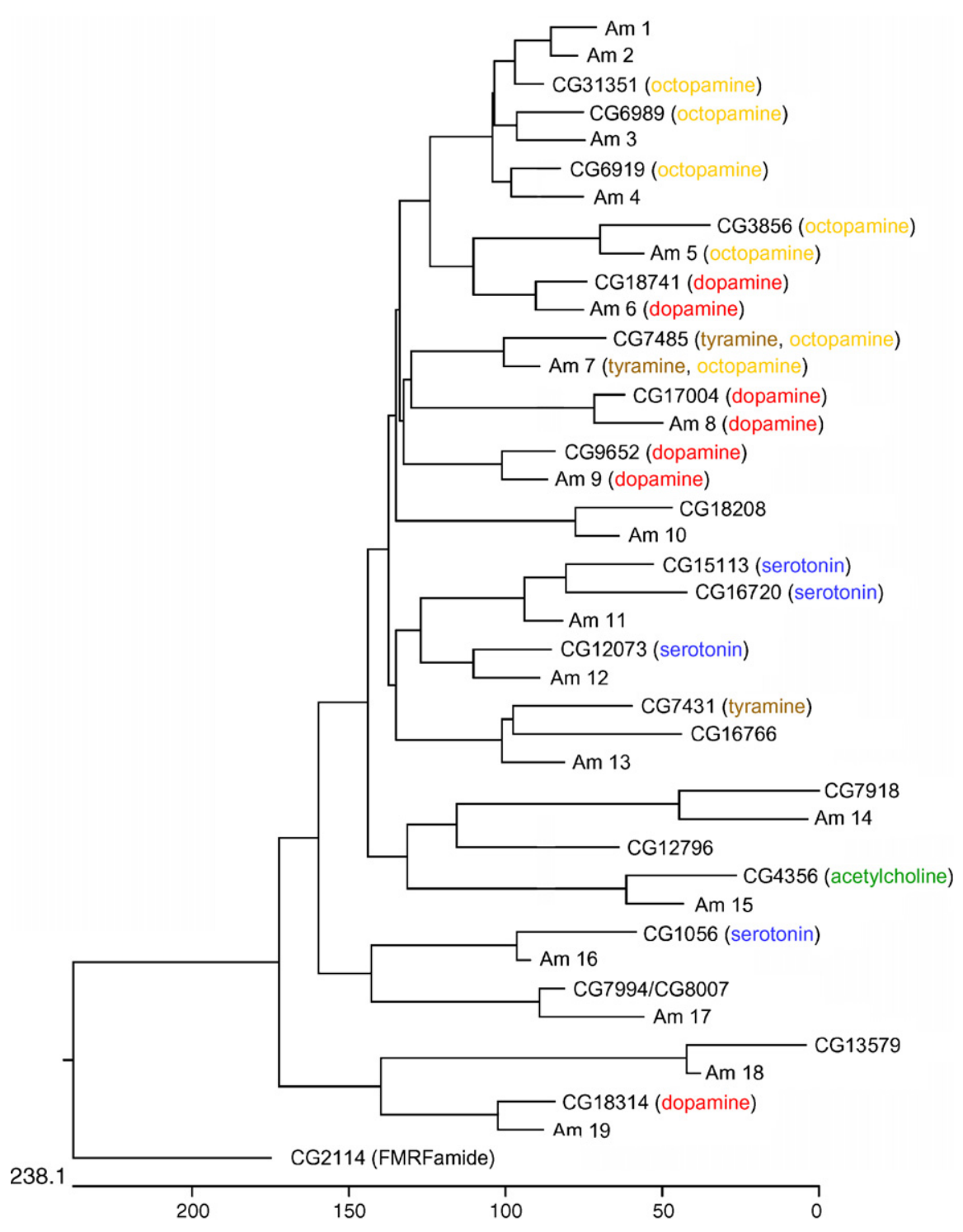

Fig. 3. Phylogenetic tree analysis of the Drosophila and honey bee biogenic amine GPCRs. The Drosophila genes are indicated by their official CG identification numbers (www.flybase.org), whereas, for reading convenience, the honey bee genes are numbered Am 1-19 (for their official GB identification numbers, see Table 1). The tree is rooted by the Drosophila FMRFamide receptor gene, CG2114. The length of each branch represents the distance between each receptor and the common ancestor of that receptor and its neighbor. The units at the bottom represent the number of amino acid residue substitutions, corresponding to this length.

GPCR genes (numbered Am 20-46, and Am 49-52 in Fig. 4, and Am 53-56 in Fig. 5), and two protein hormone GPCR genes (numbered Am 47-48 in Fig. 4). We have used the same numbering system in Tables 1 and 2 (first column), which also gives the official gene identification numbers (GB numbers) from the Honey Bee Genome Sequencing Consortium (fourth column). A short paragraph on our annotation efforts is given in (The Honey Bee Sequencing Consortium, 2006). In the following, we will describe our results in more detail.

\subsection{Biogenic amine receptors}

The known insect biogenic amines are dopamine, tyramine, octopamine, serotonin, acetylcholine, and histamine. There probably exists no adrenaline or noradrenaline in insects (Blenau and Baumann, 2001; Blenau, 2005; Roeder, 2005). In inverte- brates, histamine seems to act exclusively on histamine-gated chloride channels (Roeder, 2003), which are not GPCRs and, therefore, will not be addressed in this paper. Insect biogenic amines play a crucial role in the control of a large number of behaviors, such as learning, foraging, circadian rhythm, aggression, arousal, locomotion, and defence. But they are also involved in many other physiological processes, such as diuresis and immune responses (Blumenthal, 2003; Roeder, 2005; Birman, 2005). In the following, we will give a short description of the biogenic amine receptors present in Drosophila and the honey bee. An overview of them is given in Fig. 3 .

\subsubsection{Honey bee biogenic amine receptor genes that have been previously deorphanized}

2.1.1.1. Am 5-9. Five honey bee receptor genes have previously been cloned and their ligands identified. These 


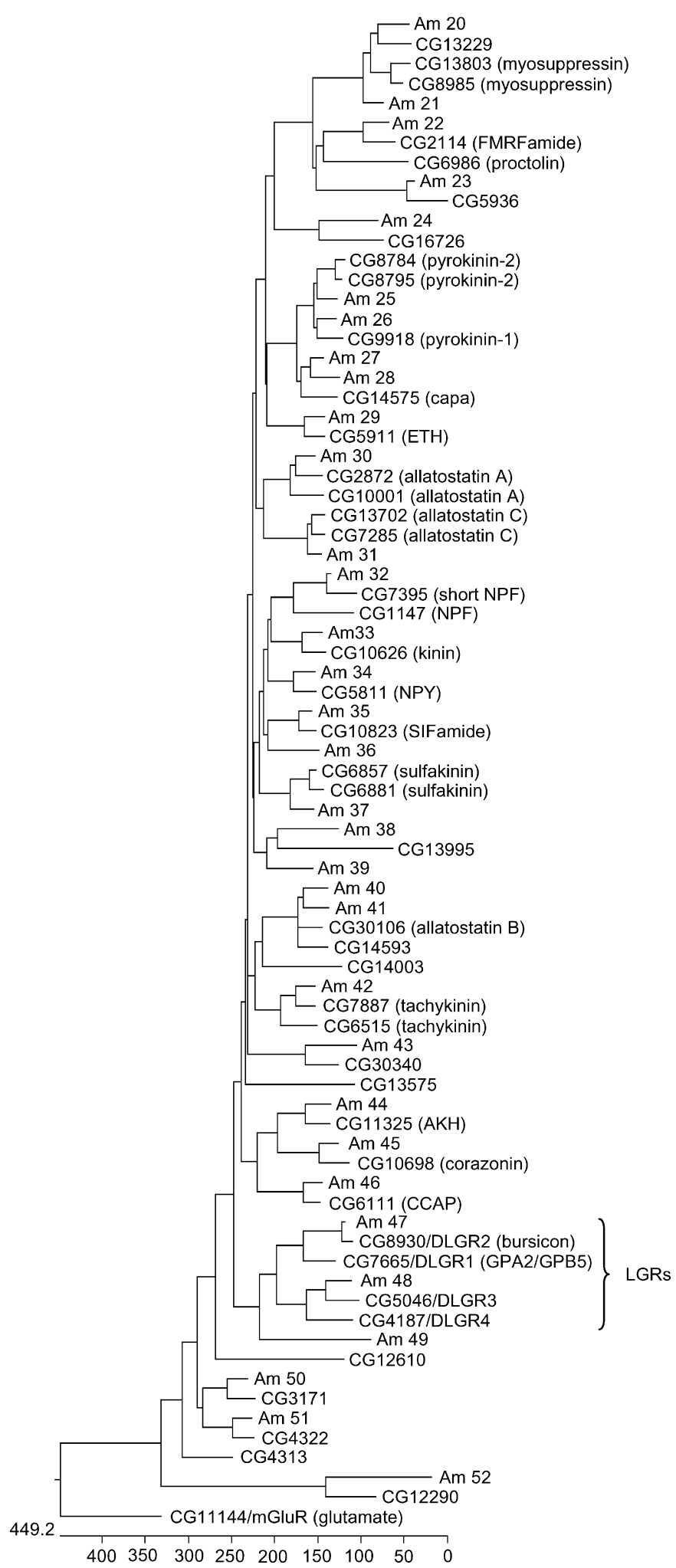

Fig. 4. Phylogenetic tree analysis of the Drosophila and honey bee neuropeptide and protein hormone GPCRs, belonging to family A (or family 1) (Gether, 2000). The honey bee receptors are numbered Am 20-52 (for official honey bee GB identification numbers, see Table 2). The tree is rooted by the Drosophila metabotropic glutamate receptor, CG11144. genes are Am 5 (octopamine), Am 6 (dopamine), Am 7 (tyramine/octopamine), Am 8 (dopamine), and Am 9 (dopamine) (Fig. 3 and Table 1) (Blenau et al., 1998, 2000; Grohmann et al., 2003; Humphries et al., 2003; Mustard et al., 2003; Beggs et al., 2005). All five deorphanized honey bee receptors have a Drosophila orthologue that also has been deorphanized and that uses the same ligand (Fig. 3).

\subsubsection{Orphan honey bee biogenic amine receptor genes that have a deorphanized Drosophila orthologue}

The following bee receptors have not been deorphanized, but have a deorphanized Drosophila orthologue:

\subsubsection{Am 1-4. Four octopamine-like receptors (orthologues} to CG31351, CG6989, and CG6919). Four Drosophila genes (CG31351, CG6989, CG6919, and CG3856) have been identified as genes coding for an octopamine receptor (Maqueira et al., 2005; Balfanz et al., 2005; Han et al., 1998). Am 1 and Am 2 are clearly orthologues to CG31351 and, therefore, likely to be honey bee octopamine receptors (Fig. 3). This is supported by our finding that Am 1 has two introns and Am 2 one intron in common (i.e., identical positions and intron phasings) with their Drosophila orthologue (Table 1). Furthermore, the Am 1 receptor protein has $61 \%$ and the Am 2 protein $65 \%$ sequence identities with the corresponding Drosophila receptor, when the TM1-TM7 regions were compared. All biogenic amine receptors have a large third intracellular loop (ic3) with little sequence conservation. When this loop is omitted in the sequence comparisons, the sequence identities become 70\% (Am 1) and 69\% (Am 2) (Table 1). All these identities strongly suggest that the two honey bee genes code for an octopamine receptor.

Am 3 is the orthologue of CG6989 and Am 4 is the orthologue of CG6919 (Fig. 3). The two honey bee genes have one or two (out of two) introns in common with their Drosophila orthologues. Furthermore, there are high sequence identities of $62-66 \%$ (67-69\% when ic3 is omitted) between the honey bee and fly receptor proteins, arguing, again, that Am 3 and Am 4 are genes, coding for honey bee octopamine receptors (Table 1).

2.1.2.2. Am 11, Am 12, and Am 16. Three serotonin-like receptors (orthologues to CG15113, CG16720, CG12073, and CG1056). There are four Drosophila GPCRs that have been identified as serotonin receptors (Witz et al., 1990; Saudou et al., 1992; Colas et al., 1995). One honey bee gene, Am 11, is the orthologue to two of them (CG15113 and CG16720) (Fig. 3). This honey bee gene has four introns in common with CG16720 and their receptor proteins have 54\% (69\%) sequence identities. Am 11 is, therefore, likely to code for a serotonin receptor (Table 1). Am 12 is the orthologue of a third Drosophila serotonin receptor (CG12073). These genes have no introns in common, but the protein sequence identities are quite high, 60\% (72\%), which suggests that Am 12 also is a serotonin receptor (Table 1). Am 16 is the orthologue of the Drosophila serotonin receptor CG1056, with which it has four introns in common. Also, the two-receptor proteins show high 


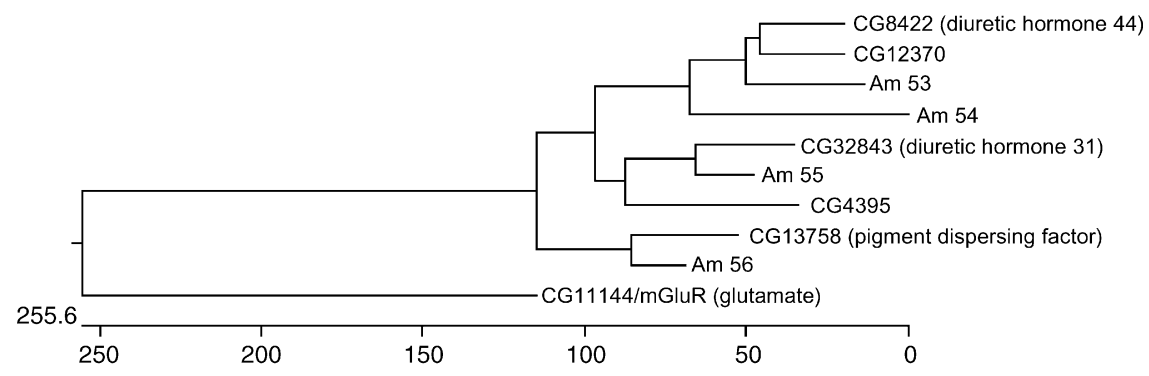

Fig. 5. Phylogenetic tree analysis of the Drosophila and honey bee neuropeptide and protein hormone GPCRs, belonging to family B (or family 2) (Gether, 2000). The honey bee receptors are numbered Am 53-56 (for official honey bee GB identification numbers, see Table 2). The tree is rooted by the Drosophila metabotropic glutamate receptor, CG11144.

sequence identities, $61 \%$ (79\%), indicating that Am 16 is likely to be a serotonin receptor gene.

\subsubsection{Am 13. One tyramine-like receptor (orthologue to} CG7431 and CG16766). We have found that CG7431 codes for a Drosophila GPCR that is specific for tyramine and that does not cross-react with octopamine (Cazzamali et al., 2005a). Its paralogue CG16766 (Fig. 3) has not been characterized, so far, but might also code for a tyramine-specific receptor. Am 13 is the honey bee orthologue of the two Drosophila receptor genes (Fig. 3). It has only one intron in common with CG7431 (Table 1). However, the sequence identities between the tworeceptor proteins, 52\% (62\%) nevertheless suggest that Am 13 is a honey bee tyramine receptor gene.

\subsubsection{Am 15. One muscarinic acetylcholine-like receptor} (orthologue to CG4356). Am 15 is the orthologue of CG4356 (Fig. 1), which has been identified as a Drosophila gene coding for a muscarinic acetylcholine receptor (mAChR) (Onai et al., 1989; Shapiro et al., 1989). Am 15 has six introns, but only two of them are common with the Drosophila gene (Table 1). Still, we believe that Am 15 is a honey bee mAChR, because the honey bee and the Drosophila receptor proteins have considerable sequence identities, 49\% (82\%) (Table 1).

\subsubsection{Am 19. One dopamine-like receptor (orthologue to} CG18314). Am 19 is the orthologue of CG18314, which has been identified as the Drosophila gene, coding for a dopamine receptor (Srivastava et al., 2005). The interesting thing is that this Drosophila receptor is modulated by steroids, such as ecdysone (Srivastava et al., 2005). Am 19 has one intron in common with CG18314 and the two receptor proteins show a high sequence identity of $70 \%$ (73\%) (Table 1), suggesting that it also is a dopamine receptor.

\subsubsection{Honey bee biogenic amine receptor genes that have an orphan Drosophila orthologue}

2.1.3.1. Am 10, Am 14, Am 17, and Am 18. Four honey bee biogenic amine receptors (Am 10, Am 14, Am 17, and Am 18) have Drosophila orthologues that have not been deorphanized, so far (Fig. 3 and Table 1). This means that we cannot propose ligands for them. Thus, we know the identified or probable ligands for 15 , or $68 \%$ of all honey bee biogenic amine GPCRs (Fig. 3). Furthermore, all honey bee biogenic amine-like receptor genes found so far have a clear Drosophila orthologue (Fig. 3).

\subsection{Neuropeptide and protein hormone receptors}

An overview of the neuropeptide and protein hormone GPCRs present in Drosophila and the honey bee is given in Fig. 4 (for the family A GPCRs) and in Fig. 5 (family B).

\subsubsection{Honey bee neuropeptide and protein hormone receptor genes that have a "deorphanized" Drosophila orthologue}

2.2.1.1. Am 21. One myosuppressin-like receptor (orthologue to CG8985 and CG13803). Insect myosuppressins are neuropeptides that generally have inhibitory actions and that block both muscle and nervous system activities (Holman et al., 1986; Vanden Broeck, 2001; Nässel, 2002; Nichols, 2003). Myosuppressin also inhibits the release of ecdysone, a steroid hormone needed for growth, molting and metamorphosis, from the prothoracic glands of silkworm larvae (Yamanaka et al., 2005). Two myosuppressin receptor genes have recently been identified in Drosophila, CG8985 and CG13803 (Egerod et al., 2003a; Johnson et al., 2003a). There is another paralogue in Drosophila, CG13229, whose ligand, however, could not be identified (Egerod et al., unpublished). The honey bee has two orthologues (Am 20 and Am 21) to these three Drosophila receptor genes. From a phylogenetic tree analysis, it is unclear which of the two honey bee orthologues represents the myosuppressin receptor (Fig. 4). Amino acid sequence alignments, focussing on identical residues, however, suggest that Am 21 is the orthologue of the two Drosophila myosuppressin receptors CG8985 and CG13803, with which it has $50-51 \%$ sequence identity (40\% with CG13229) (Table 2). In agreement with this assignment, the Am 20 receptor protein has $47 \%$ amino acid identities with the CG13229 protein (43\% and 41\% with CG13229 and CG13803). That Am 21 is the orthologue of CG13803 and CG8985, and Am 20 the orthologue of CG13229, is further supported when the genomic organizations of the five genes are compared. Am 21 has one intron in common with both CG8985 and CG13803, but none with CG13229. Am 20 has one intron in common with CG13229, but none with CG8985 and CG13803. These data, then, suggest that Am 21 is coding for a honey bee myosuppressin receptor. This conclusion has 


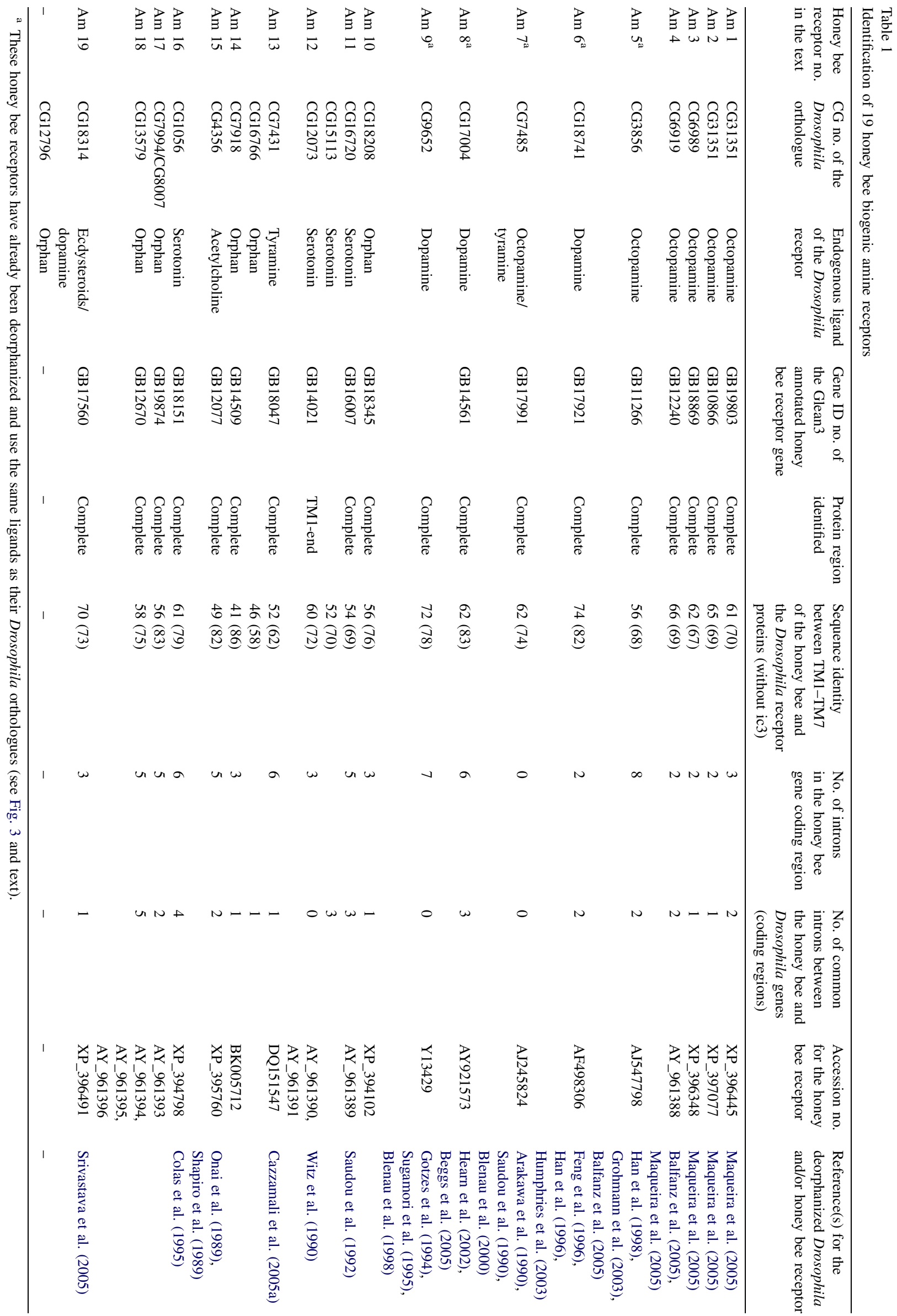




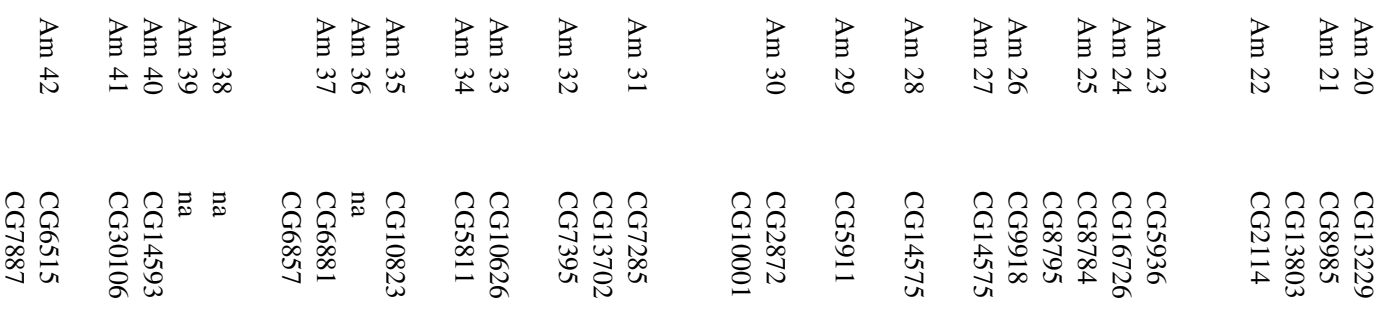

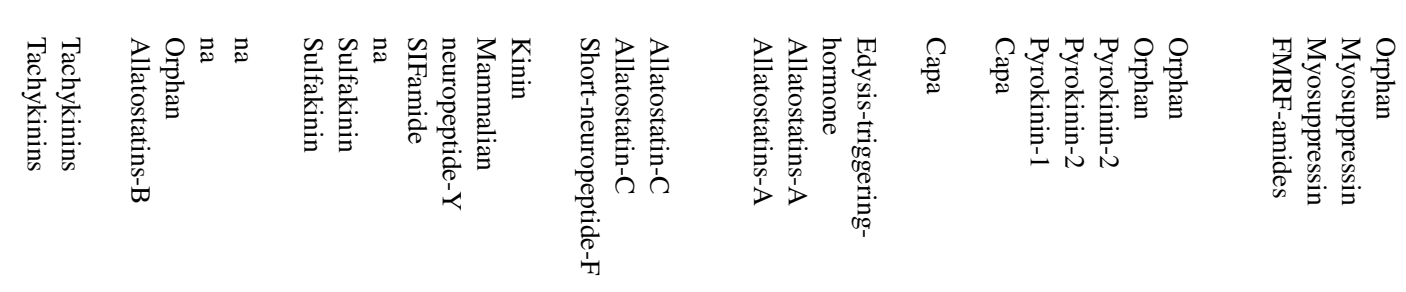

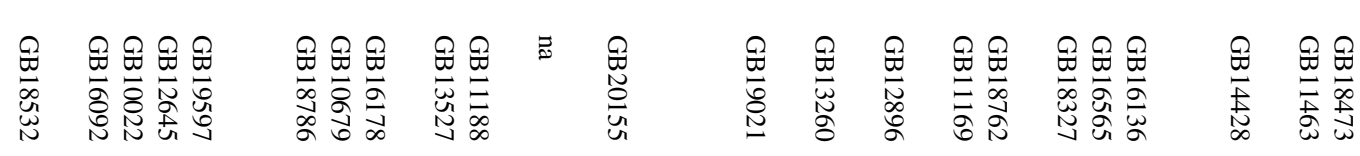

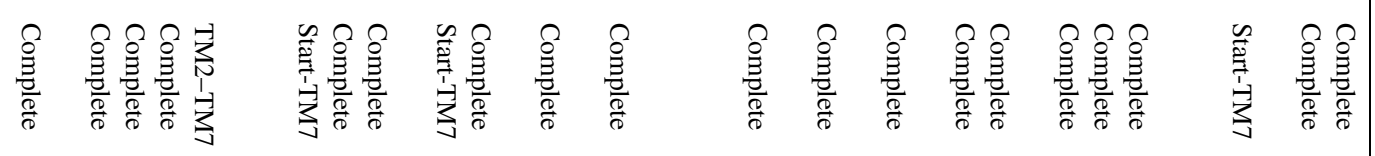

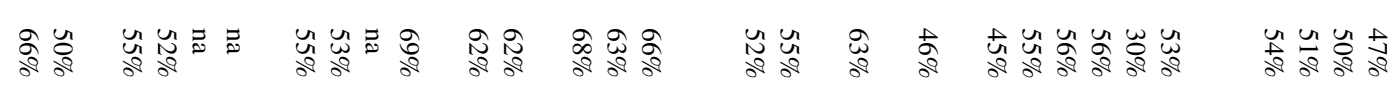

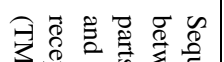

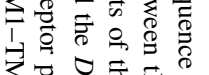

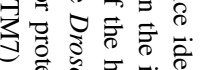

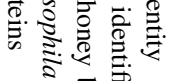

原

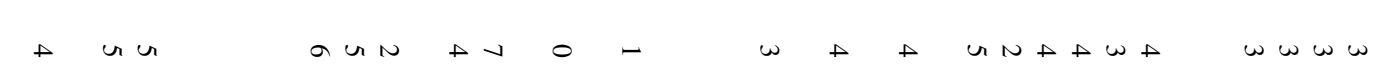

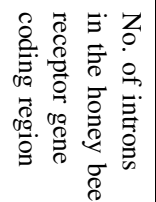

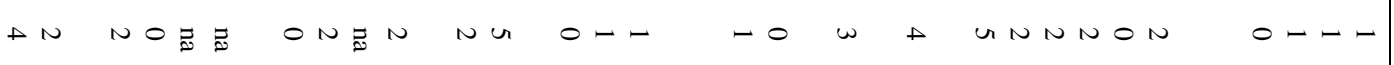

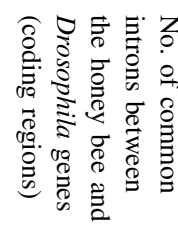

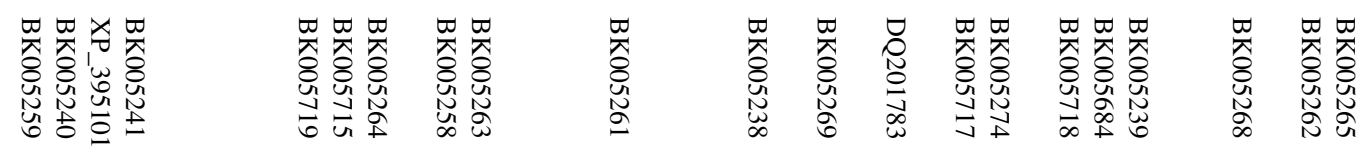
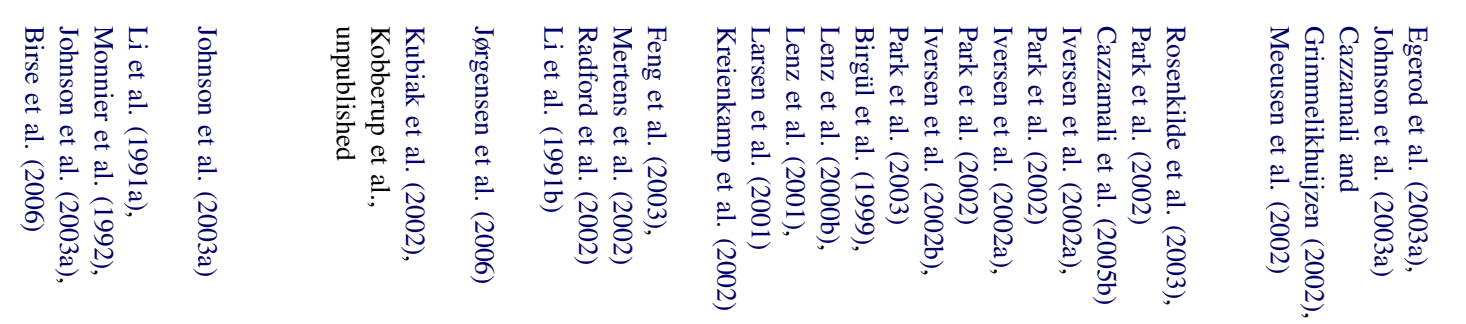

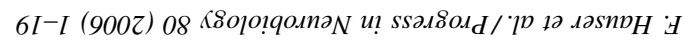

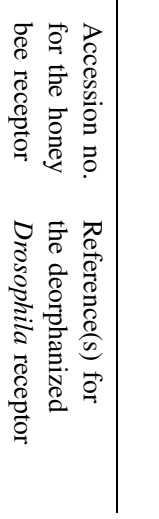




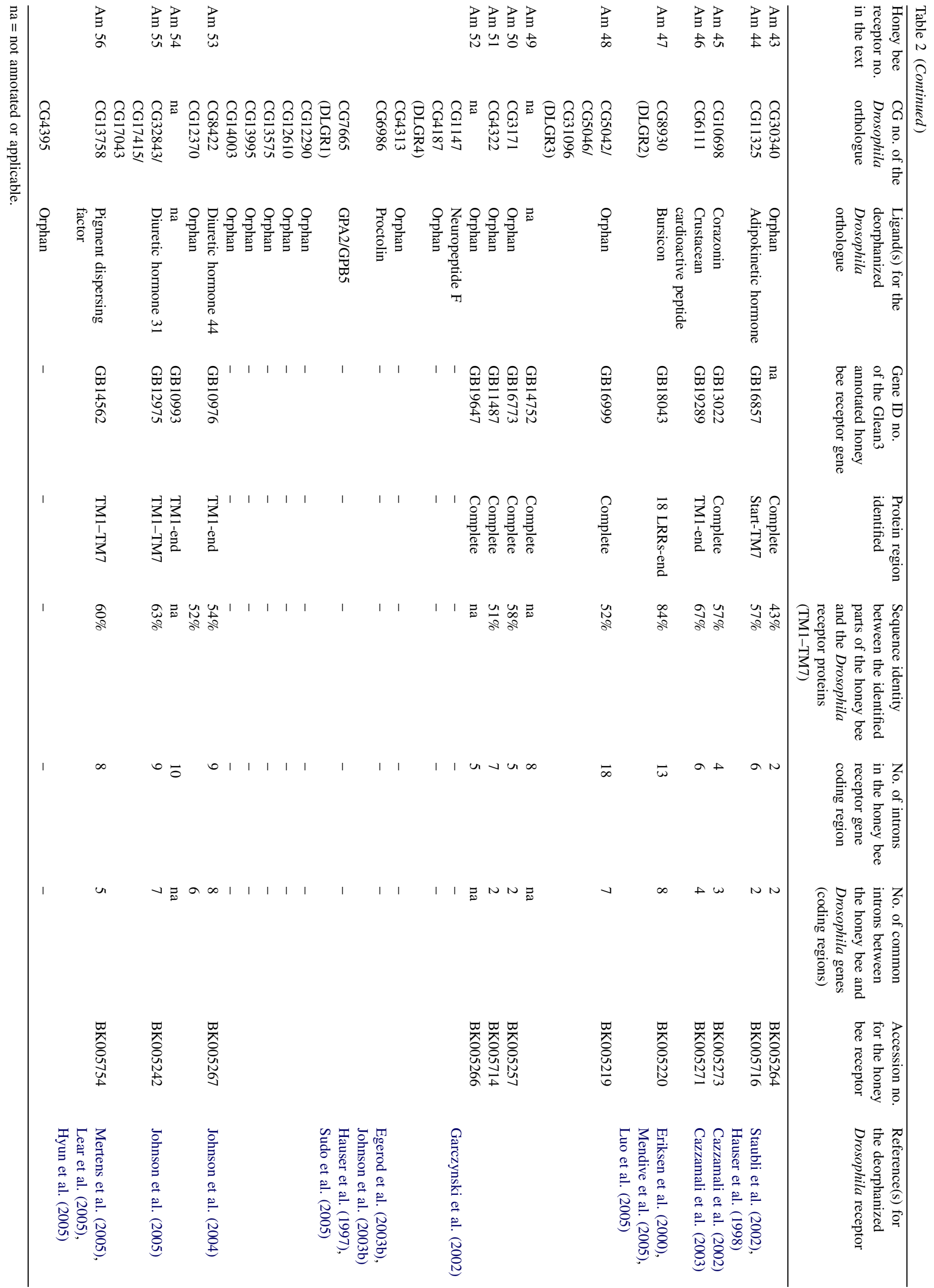


recently been confirmed by cloning and expression of Am 21 and Am 20 in $\mathrm{CHO}$ cells. Am 21 could be activated by honey bee myosuppressin, whereas, Am 20 could not (A.F. Rudolf and C.J.P. Grimmelikhuijzen, unpublished).

\subsubsection{Am 22. One FMRFamide-like receptor (orthologue to} CG2114). The invertebrate FMRFamides are small neuropeptides with the C-terminal sequence FMRFamide (Phe-Met-ArgPhe-amide). They play important roles in many physiological processes in invertebrates, such as feeding, reproduction, vision, and the regulation of muscle contraction and heart beat (Vanden Broeck, 2001; Nässel, 2002; Nichols, 2003). We and others have recently identified the first invertebrate FMRFamide receptor in Drosophila, which has the gene number CG2114 (Cazzamali and Grimmelikhuijzen, 2002; Meeusen et al., 2002). We can now find a closely related orthologue, Am 22, that probably codes for a honey bee FMRFamide-like receptor (Fig. 4). This gene contains three introns in its coding region, whereas, the coding region of the Drosophila orthologue gene is intronless (Table 2; Cazzamali and Grimmelikhuijzen, 2002). However, alignment of the honey bee FMRFamide-like receptor protein with that of Drosophila yields 54\% sequence identity (Table 2), supporting our proposal that Am 22 is an FMRFamide receptor.

\subsubsection{Am 25 and Am 26. Two pyrokinin-like receptors} (orthologues to CG9918, CG8784, and CG8795). Pyrokinins are small neuropeptides with the C-terminal sequence FXPRLamide, which are involved in various physiological processes, among them the production and release of sex pheromones from lepidopterans and pupariation in dipterans (Nässel, 2002; Verleyen et al., 2004a). The pyrokinins can be subdivided into two groups, depending on their peptide structures, and Drosophila has representatives from each class, pyrokinin-1 and -2 (Cazzamali et al., 2005b). Furthermore, Drosophila has three pyrokinin receptors, one specific for pyrokinin-1 (CG9918), and two for pyrokinin-2 (CG8784 and CG8795) (Park et al., 2002; Rosenkilde et al., 2003; Cazzamali et al., 2005b). The honey bee has two receptor genes (Am 25 and Am 26) that clearly are the orthologues to the three Drosophila pyrokinin receptor genes (Fig. 4 and Table 2). Both honey bee receptor proteins have the same sequence identities (55-56\%) to the three Drosophila receptors and their genes have the same number of introns in common with the Drosophila genes (2), making it difficult to decide whether they are pyrokinin-1 or -2 receptors (Fig. 4 and Table 2).

\subsubsection{Am 27 and Am 28. Two capa-like receptors (ortholo-} gues to CG14575). Fluid secretion (diuresis) in insects occurs in the Malpighian tubules and reabsorption of water and other small molecules takes place in the hindgut. Several insect hormones control this important process of water and salt homeostasis. There are both diuretic and antidiuretic hormones that act on the Malpighian tubules and there is only one hormone known, so far, to act on the hindgut (Coast and Garside, 2005).

The capa peptides are small neuropeptides with the Cterminal sequence FPRVamide, which have clear antidiuretic actions on the Malphigian tubules from the blood-sucking bug Rodnius proxilus and other insects (Coast and Garside, 2005; Paluzzi and Orchard, 2006), but, in contrast, have diuretic actions in Drosophila (Pollock et al., 2004). In addition, capa peptides have myotropic effects in a variety of insects (Wegener et al., 2002). We and others have recently cloned and identified a Drosophila capa receptor gene, CG14575 (Iversen et al., 2002a; Park et al., 2002). The honey bee genome contains two paralogues (Am 27 and Am 28) that are orthologues to CG14575 (Fig. 4). These honey bee genes have all five or four introns in common with the Drosophila orthologue and their gene products have $45 \%$ or $46 \%$ amino acid identities with the Drosophila capa receptor, strongly suggesting that they are honey bee capa receptors (Table 2).

\subsubsection{Am 29a and Am29b. Two ecdysis-triggering-hormone-} like receptor splice variants (orthologues to CG5911). Insects and other arthropods have an external skeleton (cuticle) that they need to exchange during growth and metamorphosis. The shedding of the cuticle is called ecdysis or molting. Ecdysis is initiated and regulated by a hormonal peptide, ecdysistriggering-hormone (ETH) (Zitnan et al., 1996). We and others, have recently identified a gene in Drosophila (CG5911) that, by alternative splicing, gives rise to two ETH receptors (CG5911-A and -B) (Iversen et al., 2002b; Park et al., 2003). Also the honey bee genome contains an ETH-like receptor gene, Am 29, that probably gives rise to two splicing variants (see accession no. BK005269). Both honey bee ETH-like receptors have high sequence identities with their Drosophila counterparts (63\% and $50 \%$ ) and the three introns known to be present in the Drosophila gene do also occur at the same positions and with the same intron phasings in the honey bee gene (Table 2).

\subsubsection{Am 30. One allatostatin-A-like receptor (orthologue to} CG2872 and CG10001). The insect allatostatins are neuropeptides that obtained their names because of their ability to inhibit juvenile hormone biosynthesis in the corpora allata, two small organs (commonly fused) near the insect brain (Woodhead et al., 1989). Juvenile hormone is a terpene that plays crucial roles in insect development and reproduction. There exist three families of allatostatins that are structurally unrelated, the allatostatinsA, -B, and -C. It appears that all insects have all three types of allatostatins, but that, in each species, only one allatostatin type inhibits juvenile hormone biosynthesis, while the other allatostatins have different inhibitory functions (Lenz et al., 2000a; Williamson et al., 2001a,b; Nässel, 2002).

The A-type allatostatins are characterized by the C-terminal sequence Y/FXFGLamide (Woodhead et al., 1989). Also Drosophila has several A-type allatostatins (Lenz et al., 2000a; Vanden Broeck, 2001). We and others have identified two Drosophila allatostatins-A receptor genes, CG2872 and CG10001 (Birgül et al., 1999; Lenz et al., 2000b, 2001; Larsen et al., 2001). We have now found that also the honey bee genome contains an orthologue (Am 30) to CG2872 and CG10001 (Fig. 4). The honey bee allatostatins-A-like receptor protein has 52-55\% sequence identities to the two Drosophila receptors. Its gene, however, shares one intron with CG10001 
and none with CG2872 and might, therefore, be somewhat more related to CG10001 (Table 2).

\subsubsection{Am 31. One allatostatin-C-like receptor (orthologue} to CG7285 and CG13702). C-type allatostatins are closely related, 15 amino-acid residues long cyclic neuropeptides that have originally been isolated from the moth Manduca sexta, where they inhibit juvenile hormone biosynthesis (Kramer et al., 1991). Also Drosophila has a C-type allatostatin (Williamson et al., 2001b). In Drosophila, two allatostatin-C receptor genes have been identified, CG7285 and CG13702 (Kreienkamp et al., 2002). The honey bee genome contains one close orthologue (Am 31) to these two Drosophila receptor genes (Fig. 4). There is a high sequence identity (63-66\%) between the honey bee receptor protein and the two Drosophila receptors. Furthermore, there is one intron in the honey bee receptor gene, which has the same position and phasing as in the Drosophila orthologues (Table 2).

\subsubsection{Am 32. One short neuropeptide F (sNPF)-like} receptor (orthologue to CG7395). Short neuropeptides F (sNPF) have been sequenced from several insects and are small neuropeptides with the C-terminal sequence RLRF/Wamide (Vanden Broeck, 2001). Several reports suggest that they are associated with reproduction and feeding in insects (Mertens et al., 2002; Lee et al., 2004). Recently, the Drosophila receptor gene for sNPF (CG7395) has been identified (Mertens et al., 2002; Feng et al., 2003). In the honey bee genome, we find a gene (Am 32) that is the orthologue to CG7395 (Fig. 4). This gene has only been identified manually by us and was missed by the Glean 3 software. Both the honey bee and the Drosophila genes have no introns in their coding regions and their gene products have high $(68 \%)$ sequence identities (Table 2).

2.2.1.9. Am 33. One kinin-like receptor (orthologue to CG10626). Insect kinins are small neuropeptides that function as diuretic hormones in the insect Malpighian tubules (Hayes et al., 1989; Coast and Garside, 2005). These peptides, which are characterized by the C-terminal sequence FXXWGamide, were first isolated from the cockroach Leucophea madeirae (Hayes et al., 1989). Furthermore, a Drosophila kinin receptor, CG10626, has recently been identified (Radford et al., 2002). The honey bee genome contains a clear orthologue to CG10626 (Fig. 4). It shares five introns with the Drosophila gene and the honey bee receptor protein has $62 \%$ identity with its Drosophila counterpart (Table 2).

\subsubsection{Am 34. One neuropeptide-Y-like receptor (ortholo-} gue to CG5811). Fifteen years ago, Li and coworkers (Li et al., 1991b) characterized the gene product of the Drosophila gene CG5811 as a neuropeptide-Y receptor, although sensu stricto no neuropeptide-Y exists in insects. Therefore, one might regard CG5811 as an orphan receptor. There is, however, a closely related long neuropeptide-Y-like peptide (called DrmNPF) in Drosophila (Brown et al., 1999; Vanden Broeck, 2001), which might be the ligand for this receptor. Still, the situation is unclear because another receptor, CG1147 (Fig. 4), has been identified by Garczynski et al. (2002) as the Drm-NPF receptor. It could be, therefore, that CG5811 is a second Drm-NPF receptor. CG5811 and CG1147 are evolutionarily related, albeit not very closely (Fig. 4). Drm-NPF clearly regulates feeding in Drosophila as does its established receptor CG1147 (Wu et al., 2005). The role of the receptor encoded by CG5811 has not been investigated yet. In the honey bee database, we could identify an orthologue to CG5811, but not to CG1147 (Fig. 4). This orthologue (Am 34) probably codes for a neuropeptide-Ylike receptor. Am 34 has two introns in common with the Drosophila receptor gene, and the two receptor proteins have $62 \%$ sequence identities (Table 2 ).

\subsubsection{Am 35. One SIFamide-like receptor (orthologue to} CG10823). SIFamide is the short name and also the $\mathrm{C}$ terminus of the Drosophila neuropeptide AYRKPPFNGSIFamide (Verleyen et al., 2004b). SIFamide has been isolated and predicted from various insects and crustaceans and appears to be extremely well conserved among these arthropods (Verleyen et al., 2004b). The function of this neuropeptide, however, is still enigmatic. This year, our research group has identified the Drosophila SIFamide receptor gene, CG10823 (Jørgensen et al., 2006). The honey bee genome contains a clear orthologue, Am 35, to this gene (Fig. 4). The two introns in the coding region are shared by both genes and the two gene products have $69 \%$ sequence identities, showing that Am 35 likely codes for a SIFamide receptor (Table 2).

\subsubsection{Am 37. One sulfakinin-like receptor (orthologue to} CG6857 and CG6881). The insect sulfakinins strongly resemble mammalian gastrin and cholecystokinin and are, similar to their mammalian counterparts, also involved in feeding (Wei et al., 2000). In Drosophila, two sulfakinin receptor genes have been identified, CG6857 and CG6881 (Kubiak et al., 2002; Kobberup, Hauser, and Grimmelikhuijzen, unpublished). The honey bee genome contains one orthologue (Am 37) to these two Drosophila sulfakinin receptor genes (Fig. 4). This gene clearly resembles much more CG6881 than CG6857, because it has two introns in common with the first and none with the second Drosophila gene. On the other hand, its gene product has 53\% sequence identity with the CG6881 receptor protein and $55 \%$ with the CG6857 receptor (Table 2).

2.2.1.13. Am 41. Two allatostatin-B-like receptors (orthologues to CG30106 and CG14593). B-type allatostatins (also called MIPs) are neuropeptides that were initially isolated from locusts based on their myoinhibitory activities (Schoofs et al., 1991). These peptides, however, also inhibit juvenile hormone biosynthesis and can, therefore, be called allatostatins (Lorenz et al., 1995). B-type allatostatins are characterized by the Cterminal sequence W(X) 6 Wamide (Schoofs et al., 1991; Lorenz et al., 1995; Williamson et al., 2001a). An allatostatin-B receptor gene, CG30106, has recently been identified in Drosophila (Johnson et al., 2003a). There exists a close paralogue to this gene, CG14593, in Drosophila (Fig. 4) that has not been deorphanized, so far, but that also likely codes for an allatostatin-B receptor. The honey bee genome contains two 
genes (Am 40 and Am 41) that closely resemble the two Drosophila receptor genes (Fig. 4). Analysis of their genomic organizations suggests that Am 41 is more related to CG30106, because it has two introns in common with this gene, whereas Am 40 has no common introns either with CG30106 or with CG14593 (Table 2). These findings indicate that Am 41 is an allatostatin-B-like receptor, whereas, the status of Am 40 is still uncertain, although it might well be a second allatostatin-B-like receptor. It is interesting to mention that Am 41 is also found in the honey bee brain EST library (http://titan.biotec.uiuc.edu/ bee/honeybee_project.htm), showing that this honey bee allatostatin-B-like receptor is a brain receptor.

\subsubsection{Am 42. One tachykinin-like receptor (orthologue to} CG6515 and CG7887). The insect tachykinins are mostly known for their stimulatory actions on the insect visceral muscles, but they are also involved in other processes, such as diuresis, where they function as diuretic hormones on the Malpighian tubules (Vanden Broeck, 2001; Nässel, 2002; Coast and Garside, 2005). The Drosophila genome contains two tachykinin receptor genes, CG6515 and CG7887 ( $\mathrm{Li}$ et al., 1991a; Monnier et al., 1992; Johnson et al., 2003a; Birse et al., 2006). In the honey bee genome, we could identify one orthologue, Am 42 (Fig. 4). The honey bee receptor protein has high sequence identities (50\% and 66\%) with its two Drosophila counterparts, and its gene has four introns in common with CG7887 and two with CG6515 (Table 2).

\subsubsection{Am 44. One adipokinetic-hormone-like receptor} (orthologue to CG11325). The insect adipokinetic hormones are a large family of structurally related neuropeptides that are involved in the mobilization of sugar (trehalose) and lipids from the insect fat body during energy requiring activities such as flight and locomotion (Gäde et al., 1997). We have recently identified a Drosophila adipokinetic hormone receptor, CG11325, and an adipokinetic-hormone receptor from the silkworm B. mori (Staubli et al., 2002). We now find that a similar adipokinetic hormone receptor gene (Am 44) also occurs in the honey bee genome (Fig. 4). This gene has two introns in common with its Drosophila orthologue CG11325. The honey bee adipokinetic-hormone-like receptor has $57 \%$ sequence identity with the Drosophila receptor (Table 2).

\subsubsection{Am 45. One corazonin-like receptor (orthologue to} CG10698). The insect neuropeptide corazonin (this name was derived from the Spanish word corazón, meaning heart) has originally been isolated from cockroaches, because of its cardio-excitatory actions on isolated cockroach hearts (Veenstra, 1989; Vanden Broeck, 2001; Nässel, 2002). In locusts, corazonin is involved in stress reactions and induces a characteristic black pattern in the cuticle of crowding animals that are preparing for swarming (Tawfik et al., 1999). Recently, we and others identified the Drosophila gene coding for a corazonin receptor, CG10698 (Cazzamali et al., 2002; Park et al., 2002). We have found that also the honey bee genome contains a corazonin-like receptor gene (Am 45), closely related to CG10698 (Fig. 4). The honey bee receptor protein has
$57 \%$ sequence identity with the CG10698 receptor. Its gene has three introns in common with CG10698 (Table 2).

\subsubsection{Am 46. One crustacean cardioactive peptide-like} receptor (orthologue to CG6111). Crustacean cardioactive peptide (CCAP) is a small cyclic neuropeptide originally isolated from crustaceans, but that is also present, with identical sequence, in insects (Vanden Broeck, 2001; Nässel, 2002). CCAP in insects has myotropic and cardioactive actions, but also plays a role in certain motor behaviors associated with ecdysis (Cheung et al., 1992; Gammie and Truman, 1999). We and others, have recently identified a CCAP receptor gene in Drosophila, CG6111 (Park et al., 2002; Cazzamali et al., 2003). The honey bee genome also contains a CCAP-like receptor gene (Am 46) which has four introns in common with its Drosophila orthologue CG6111 (Table 2 and Fig. 4). The two receptor proteins show high sequence identities (67\%) (Table 2).

\subsubsection{Am 47. One bursicon-like receptor (orthologue to} CG8930). Drosophila has four leucine-rich repeats-containing GPCRs (LGRs) that we cloned and named DLGR1-4 (Hauser et al., 1997; Eriksen et al., 2000; Bohn, Williamson, and Grimmelikhuijzen, unpublished). We and others have recently also identified the natural ligand for DLGR2, which is a heterodimeric cystine-knot protein with bursicon bioactivity (Mendive et al., 2005; Luo et al., 2005). Bursicon was described more than 40 years ago as a neurohormone that causes hardening and tanning of the soft cuticle from a newly hatched fly after adult ecdysis (Fraenkel and Hsiao, 1962; Fraenkel et al., 1966). Later studies showed that bursicon also induces apoptosis of the wing epithelial cells after completed wing expansion (Kimura et al., 2004). The honey bee genome contains a clear orthologue of the Drosophila bursicon receptor gene (CG8930/DLGR2) (Fig. 4). This gene, Am 47, is present in one contig, which contains the information for the whole 7TM region plus 18 Leurich repeats (LRRs), which are located in the extracellular $\mathrm{N}$ terminus of the receptor and which constitute the ligand-binding site. The honey bee receptor has a very high sequence identity (84\%) with DLGR-2. Its gene has eight introns in common with CG8930 (Table 2). We could also identify a gene in the honey bee genome, coding for bursicon (Mendive et al., 2005). We made a highly interesting discovery here (Mendive et al., 2005), namely that the honey bee bursicon was not, as in Drosophila, a heterodimeric protein, coded for by two genes, but that a single gene might yield a protein with two domains, each corresponding to the Drosophila monomers. Taking into account the basal evolutionary position of Hymenoptera (Savard et al., 2006), these findings suggest that, during early insect evolution, bursicon was a monomer, encoded for by a single gene.

2.2.1.19. Am 53 and Am 55. Two diuretic hormone-like receptors (orthologues to CG8422, CG12370, and CG32843). There are two diuretic hormones (named DH) acting on the insect Malpighian tubules that are longer neuropeptides (Coast et al., 2001; Coast and Garside, 2005). One is structurally related to mammalian calcitonin and the Drosophila calcitonin-like peptide is called Drome- $\mathrm{DH}_{31}$ 
(Coast et al., 2001), whereas the other is structurally related to mammalian corticotropin-releasing-factor (CRF) and in Drosophila is called Drome- $\mathrm{DH}_{44}$ (Cabrero et al., 2002). Drome$\mathrm{DH}_{31}$ and Drome- $\mathrm{DH}_{44}$ are not structurally related. Two Drosophila DH receptors have recently been identified, CG32843 (for Drome- $\mathrm{DH}_{31}$ ) and CG8422 (for Drome-DH 44 ) (Johnson et al., 2004, 2005) (Fig. 5). These receptors, like all the other receptors shown in Fig. 5, belong to the family B (or family 2) type of GPCRs, in contrast to the receptors from Figs. 3 and 4, which are family A (or family 1) type GPCRs (Gether, 2000). We have now found a honey bee gene, Am 55, that is a clear orthologue to CG32843. Am 55 has seven introns in common with CG32843 and their gene products have $63 \%$ sequence identity, strongly suggesting that Am 55 is a $\mathrm{DH}_{31^{-}}$ like receptor (Table 2).

We have also found another honey bee receptor gene, Am 53 , that is clearly related to CG8422. This gene has eight introns in common with CG8422 and their gene products show 54\% sequence identities (Table 2). Thus, it appears that Am 53 is a Drome- $\mathrm{DH}_{44}$-like receptor. In a phylogenetic tree analysis (Fig. 5) Am 53 is about equally related to both CG8422 (the Drome- $\mathrm{DH}_{44}$ receptor) and CG12370 (which is an orphan). However, the genomic organization of Am 53 suggests that the honey bee gene is more closely related to CG8422 (with which it has eight introns in common) than to CG12370 (where six introns are in common) (Table 2).

2.2.1.20. Am 56. One PDF-like receptor (orthologue to CG13758). Pigment dispersing factor (PDF) has first been isolated from crustaceans, because of its pigment cell dispersing activity (Riehm and Rao, 1982), but a structurally related neuropeptide has later also been found in insects (Rao et al., 1987). The best-known function of PDF in insects is its role in circadian rhythmicity, where it appears to be the principal transmitter, mediating the output of central clock neurons (Renn et al., 1999; see, however, Kula et al., 2006). Last year, three research groups independently published the identification of the Drosophila gene CG13758 as the one coding for the PDF receptor (Hyun et al., 2005; Lear et al., 2005; Mertens et al., 2005). Also in the honey bee genome there exists a clear orthologue of CG13758, Am 56 (Fig. 5). The honey bee receptor has $60 \%$ sequence identity with the Drosophila receptor and its gene has five introns in common with the Drosophila PDF receptor gene (Table 2). Circadian rhythms play crucial roles in the behavior and physiology of honey bees and the identification of a bee PDF receptor may represent an important advance in honey bee chronobiology.

\subsubsection{Honey bee neuropeptide and protein hormone receptor genes that have an "orphan" Drosophila orthologue}

The following honey bee neuropeptide and protein hormone orphan GPCR genes have Drosophila orthologues that also are orphans: Am 20 (orthologue to CG13229), Am 23 (orthologue to CG5936), Am 24 (orthologue to CG16726), Am 43 (CG30340), Am 48 (CG5046/DLGR3), Am 50 (CG3171), Am 51 (CG4322), and Am 52 (CG12290).
The information on the above-mentioned honey bee receptors can be found in Table 2, Fig. 4, and Fig. 5 and need little additional explanation. However, we would like to expand somewhat on Am 48 and its Drosophila orthologue CG5046/DLGR3.

The DLGR3 gene has been wrongly annotated by flybase (www.flybase-org), where three separate genes are proposed, CG5042, CG5046 and CG31096, which, in fact, are exons of one gene, DLGR3 (Bohn and Williamson, unpublished). Of all four Drosophila DLGRs, Am 48 is most closely related to the corrected DLGR3 (Fig. 4). One contig contains the information for the whole 7TM region plus three LRRs in the extracellular $\mathrm{N}$ terminus. This Am 48 protein has 52\% sequence identity with DLGR3. Its gene has seven introns in common with the corrected DLGR3 gene (Table 2).

\subsubsection{Honey bee neuropeptide and protein hormone receptor genes that do not have a clear Drosophila orthologue}

We found five receptors, Am 36, Am 38, Am 39, and Am 49, belonging to family A (Fig. 4 and Table 2), and Am 54, belonging to family B (Fig. 5 and Table 2) that apparently do not have orthologues in Drosophila. All of them, however, do have orthologues in the beetle Tribolium castaneum, so they are not honey bee-specific (http://www.bioinformatics.ksu.edu/ BeetleBase/).

\subsubsection{Drosophila neuropeptide and protein hormone receptor genes that do not have a honey bee orthologue}

We did not find clear-cut honey bee orthologues for the following Drosophila neuropeptide and protein hormone GPCR genes: CG6986 (proctolin receptor), CG1147 (NPF receptor), CG14003 (orphan), CG13575 (orphan), CG12610 (orphan), CG4313 (orphan), and CG4395 (orphan) (Figs. 4 and 5 from top to bottom). These receptors might be specific for Drosophila (or for Diptera in general). This, however, is probably not true for CG6986 (the proctolin receptor gene), because the proctolin neuropeptide occurs in many other insects and even in crustaceans (Vanden Broeck, 2001; Nässel, 2002). The absence of the proctolin receptor gene in the honey bee, does not come as a surprise, because the receptor and its ligand genes are apparently also absent in the genomes from the malaria mosquito A. gambiae, and the silkworm B. mori (M. Williamson, unpublished).

\subsubsection{Neuropeptide and protein hormone receptor} paralogues that are present in Drosophila, but that are absent in the honey bee genome

Many of the Drosophila neuropeptide and protein hormone GPCR genes occur in pairs, triplets or quadruplets and both their genomic organizations and gene products are structurally closely related. These genes have probably originated by recent gene duplications and are called paralogues. Very often these paralogue receptors are still using the same or closely related ligands. In many cases these paralogue receptors are lacking in the honey bee genome. In the following, we will give some examples to clarify this point 
(mainly those, where the Drosophila orthologues have been deorphanized).

There are two myosuppressin-like receptor genes in the honey bee (Am 20 and Am 21 in Fig. 4), whereas, there are three paralogues (CG13229, CG13803 and CG8985) in Drosophila. There are two pyrokinin-like receptors in the bee (Am 25 and Am 26), whereas, there are three paralogues (CG8784, CG8795, and CG9918) in Drosophila. There is one allatostatin-A-like receptor in the bee (Am 30), while there are two in Drosophila (CG2872 and CG10001). There is one allatostatin-C-like receptor in the honey bee (Am 31), while there are two in Drosophila (CG13702 and CG7285). There is one sulfakininlike receptor in the honey bee (Am 37), whereas, there are two in Drosophila (CG6857 and CG6881). There is one tachykinin-like receptor in the honey bee (Am 42), whereas, there are two in Drosophila (CG7887 and CG6515). Finally, there are two LGRs in the honey bee (Am 47 and Am 48), whereas, there are four in Drosophila (DLGR 1-4 in Fig. 4).

\subsubsection{Neuropeptide and protein hormone receptor paralogues that are present in the honey bee, but absent in Drosophila}

There are two situations, where the honey bee has more neuropeptide/protein hormone GPCR paralogues than Drosophila. These are Am 27 and Am 28, which are both orthologues to the single Drosophila capa receptor gene, CG14575, and Am 38 and Am 39, which appear to be paralogues to the single Drosophila orphan receptor gene, CG13995 (Fig. 4).

\section{General discussion}

In this paper, we have identified 56 neurohormone GPCRs in the honey bee. Of these, 35 are neuropeptide, two are protein hormone, and 19 are biogenic amine GPCRs (Figs. 3-5). Of the 19 biogenic amine receptors, five have already been cloned and deorphanized (Am 5-9 in Fig. 3). Of the remaining 14 biogenic amine receptor genes, 10 have close Drosophila orthologues that have been deorphanized, so we know what the likely ligands are for the honey bee receptors. Of the two protein hormone (LGR) receptor genes, one (Am 47, Fig. 4) has a close orthologue in Drosophila that has been identified as a bursicon receptor gene (Mendive et al., 2005; Luo et al., 2005). Furthermore, the ligand bursicon has also been identified in the honey bee genome (GB11959; Mendive et al., 2005), so Am 47 is likely to be the bursicon receptor. None of the 35 neuropeptide receptors in the honey bee has been deorphanized and published, so far. However, 23 neuropeptide receptor genes have a close orthologue in Drosophila that has been deorphanized, so we know, again, what the likely ligands for these 23 honey bee receptors are. In conclusion, therefore, we know the ligands or the likely ligands for 39 of the 56 honey bee neurohormone GPCRs described in this study (70\%). This is one of the major outcomes from our current analyses.

Of course, it would be very helpful for the interpretation of the honey bee neurohormone GPCRs also to add a table to this review, listing all neuropeptide and protein hormone genes present in Apis. However, our knowledge on these genes is still very fragmentary. Our own group has annotated honey bee preprohormone genes for $\mathrm{AKH}$, corazonin, CCAP, myosuppressin, pyrokinins and SIFamide (K. Hansen et al., unpublished). Bursicon, as mentioned earlier, has also been annotated (Mendive et al., 2005). Furthermore, the presence of allatostatin-A, corazonin, myosuppressin, tachykinins, pyrokinins, and SIFamide in the honey bee has also been experimentally confirmed by mass spectrometry (Audsley and Weaver, 2006; Verleyen et al., 2006). These neuropeptides are all ligands belonging to the 39 likely (or known) ligands mentioned earlier. In the case of own annotated honey bee neuropeptides, we have also tested them on the corresponding annotated receptors (Am 21, Am 25, Am 26, Am 35, Am 4446; see Fig. 4) and found that they were specifically activated, thereby confirming at least some of our annotations (K. Hansen et al., unpublished).

The honey bee is an advanced insect in terms of learning, navigation, and social behavior (Elekonich and Roberts, 2005) and, thus, quite different from Drosophila and many other nonhymenopteran insects. A comparison between the genomes from the honey bee and the fruitfly could possibly reveal the genes that are involved in higher brain functions and sociality. Because neurohormone receptors and their ligands are expected to play a central role in learning and behavior of animals, it is especially interesting to look at their genes, using such a comparison. A comparison of the biogenic amine receptor genes between the honey bee and Drosophila (Fig. 3) did not show a clear difference. The numbers are about the same (19 biogenic amine receptor genes in the bee, 21 in the fruitfly) and only in one case (Am 1 and Am 2, which both are octopaminelike receptors), does the bee have more paralogues than the fruitfly (CG7078). It would be interesting to determine what the functions of these two honey bee octopamine-like receptors are and whether they are important for behavior.

There are larger differences between the honey bee and the fruitfly, when we compare their neuropeptide and protein hormone GPCRs (Figs. 4 and 5). First, there is a difference in number. Drosophila has 39 neuropeptide GPCRs and four protein hormone GPCRs (DLGRs) belonging to family A, and five neuropeptide GPCRs belonging to family B. For the honey bee, these numbers are 31, 2, and 4 (Figs. 4 and 5). The reasons for the larger numbers of neuropeptide and protein hormone GPCRs in the fruitfly, are probably gene duplications during fly evolution, which created a large number of paralogues. There are about 22 neuropeptide and protein hormone GPCR paralogues in the fruitfly compared to about 12 in the bee (Figs. 4 and 5). These gene duplications have probably occurred late in fly (dipteran) evolution, because an inspection of the genome from the malaria mosquito A. gambiae revealed fewer GPCR paralogues than in the fruitfly. Thus, although the honey bee is much more advanced than the fruitfly in terms of learning and behavior, the number of neurohormone genes is considerably less.

Still, the honey bee is not fully inferior to the fruitfly with respect to neurohormone GPCRs. There are five GPCR genes in the honey bee that do not have their counterparts in the fly. These genes are Am 36 (GB10679), Am 38 (GB19597), Am 39 (GB12645), Am 49 (GB14752), and Am 54 (GB10993). 
However, all five genes have orthologues in the beetle $T$. castaneum and are, therefore, not specific for the honey bee.

During this study, we made several interesting observations with respect to neurohormone receptor evolution and the evolution and co-evolution of their ligands. For the neuropeptide and protein hormone GPCRs (Figs. 4 and 5), it appears to be such that, when needed during evolution, extra receptors were established by gene duplications. These new receptors could use the same ligand (for example, myosuppressin, top Fig. 4, is used by both CG13803 and CG8985), or, when ligand interference occurs (which would be impractical), new ligands could be formed by amino acid residue substitutions. An example of the last situation are the paralogues CG9918, CG8784, and CG8795 in the top part of Fig. 4, which use slightly different pyrokinin ligands, showing little crossreactivity (Rosenkilde et al., 2003; Cazzamali et al., 2005a). In this way, a very large number of receptors and ligands can be created during evolution (Park et al., 2002; Cazzamali et al., 2005a).

This type of co-evolution between receptors and ligands does apparently not occur in biogenic amine GPCRs (Fig. 3). The reason for this is probably that the biogenic amine molecule is rather small and that very little structural variation is tolerated by the ligand-binding pocket of the GPCR. In short, what we see with this type of GPCR is that gene duplications also occur during evolution. Sometimes the same ligands are still being used by the paralogue receptors (for example, CG15113 and CG16720, middle of Fig. 3, both use serotonin). However, serotonin as a ligand is not confined to evolutionarily closely related GPCRs, because it is also used by a very distantly related receptor, CG1056 (bottom of Fig. 3). Another example is dopamine, which is used by two relatively closely related receptors, CG17004 and CG9652 (middle part of Fig. 3), but also by two distantly related receptors CG18741 (top part of Fig. 3) and CG18314 (bottom of Fig. 3). Thus, it seems that during biogenic amine GPCR evolution, new receptors evolved (probably by gene duplication) that needed new ligands. The only way (because of structural constrains) to obtain such new ligands was by "borrowing" from other systems. This caused a "ligand-hop" during receptor evolution. Because each Drosophila biogenic amine GPCR gene has a closely related honey bee orthologue, using, where identified, the same ligand (Fig. 3), these "ligand-hops" have occurred before the split of the ancestors of the present-day flies (Diptera) and honey bees (Hymenoptera), which is about 350 million years ago (Douzery et al., 2004).

\section{Methods}

D. melanogaster neurohormone $\mathrm{G}$ protein-coupled receptor proteins were used as probes to search for similar proteins in Apis mellifera. tBLASTn searches were performed on the genomic sequences from various releases of the Honey Bee Genome Project (Amel_1.0 to Amel_4.0; http:// www.hgsc.bcm.tmc.edu/projects/honeybee/). The full sequences of the candidate Apis receptor proteins were identified using a combination of Invitrogen Vector NTI Advance 9.0 package (InforMax), the Lasergene DNA Software package (DNASTAR), several Web-based gene prediction programs, and the official set of Glean3 predictions (The Honey Bee Sequencing Consortium, 2006). The prediction server TMHMM (v. 2.0) from the Center for Biological Sequence Analysis, BioCentrum-DTU (www.cbs.dtu.dk), was used for analysis of the secondary structure of the Apis receptor proteins. All manually annotated or Glean3 predicted but manually curated gene sequences were submitted to GenBank (Tables 1 and 2). These sequences were also fully or partially cloned by PCR. We used only the amino acid sequences from TM1 to TM7 for the construction of the phylogenetic trees (Figs. 3-5). These phylogenetic tree analyses were done, using the DNASTAR software package.

\section{Note added in proof}

After this review went to press, a paper was published (Schlenstedt et al., 2006), where gene Am 12 (Fig. 3) was experimentally identified (deorphanized) as a honey bee serotonin receptor gene, thus confirming our annotation.

\section{Acknowledgements}

We thank Sarah Preisler for typing the manuscript, Kristoffer Egerod for supplying Fig. 2, and the Danish Research Agency (Research Council for Nature and Universe), Lundbeck Foundation, Carlsberg Foundation, and Novo Nordisk Foundation (Fabrikant Vilhelm Pedersen og Hustrus Mindelegat) for financial support.

\section{References}

Adams, M.D., Celniker, S.E., Holt, R.A., Evans, C.A., Gocayne, J.D., Amanatides, P.G., Scherer, S.E., Li, P.W., Hoskins, R.A., Galle, R.F., et al., 2000. The genomic sequence of Drosophila melanogaster. Science 287, 21852195.

Arakawa, S., Gocayne, J.D., McCombie, W.R., Urquhart, D.A., Hall, L.M., Fraser, C.M., Venter, J.C., 1990. Cloning, localization, and permanent expression of a Drosophila octopamine receptor. Neuron 4, 343-354.

Audsley, N., Weaver, R.J., 2006. Analysis of peptides in the brain and corpora cardiaca-corpora allata of the honey bee, Apis mellifera using MALDITOF mass spectrometry. Peptides 27, 512-520.

Balfanz, S., Strünker, T., Frings, S., Baumann, A., 2005. A family of octopamine receptors that specifically induce cyclic AMP production or $\mathrm{Ca}^{2+}$ release in Drosophila melanogaster. J. Neurochem. 93, 440-451.

Beggs, K.T., Hamilton, I.S., Kurshan, P.T., Mustard, J.A., Mercer, A.R., 2005. Characterization of a D2-like dopamine receptor (AmDOP3) in honey bee, Apis mellifera. Insect Biochem. Mol. Biol. 35, 873-882.

Birgül, N., Weise, C., Kreienkamp, H.-J., Richter, D., 1999. Reverse physiology in Drosophila: identification of a novel allatostatin-like neuropeptide and its cognate receptor structurally related to the mammalian somatostatin/galanin/opioid receptor family. EMBO J. 18, 5892-5900.

Birman, S., 2005. Arousal mechanisms: speedy flies don't sleep at night. Curr. Biol. 15, R511-R513.

Birse, R.T., Johnson, E.C., Taghert, P.H., Nässel, D.R., 2006. Widely distributed Drosophila $\mathrm{G}$ protein-coupled receptor (CG7887) is activated by endogenous tachykinin-related peptides. J. Neurobiol. 66, 33-46.

Blenau, W., 2005. Cellular actions of biogenic amines. Arch. Insect Biochem. Physiol. 59, 99-102.

Blenau, W., Baumann, A., 2001. Molecular and pharmacological poperties of insect biogenic amine receptors: lessons from Drosophila melanogaster and Apis mellifera. Arch. Insect Biochem. Physiol. 48, 13-38.

Blenau, W., Erber, J., Baumann, A., 1998. Characterization of a dopamine D1 receptor from Apis mellifera: cloning, functional expression, pharmacology, and mRNA localization in the brain. J. Neurochem. 70, 15-23.

Blenau, W., Balfanz, S., Baumann, A., 2000. Amtyr1: characterization of a gene from honey bee (Apis mellifera) brain encoding a functional tyramine receptor. J. Neurochem. 74, 900-908. 
Blumenthal, E.M., 2003. Regulation of chloride permeability by endogenously produced tyramine in the Drosophila Malpighian tubule. Am. J. Physiol. Cell Physiol. 284, C718-C728.

Brown, M.R., Crim, J.W., Arata, R.C., Cai, H.N., Chun, C., Shen, P., 1999. Identification of a Drosophila brain-gut peptide related to the neuropeptide Y family. Peptides 20, 1035-1042.

Cabrero, P., Radford, J.C., Broderick, K.E., Costes, L., Veenstra, J.A., Spana, E.P., Davies, S.A., Dow, J.A., 2002. The Dh gene of Drosophila melanogaster encodes a diuretic peptide that acts through cyclic AMP. J. Exp. Biol. 205, 3799-3807.

Cazzamali, G., Grimmelikhuijzen, C.J.P., 2002. Molecular cloning and functional expression of the first insect FMRFamide receptor. Proc. Natl. Acad. Sci. U.S.A. 99, 12073-12078.

Cazzamali, G., Saxild, N.P.E., Grimmelikhuijzen, C.J.P., 2002. Molecular cloning and functional expression of a Drosophila corazonin receptor. Biochem. Biophys. Res. Commun. 298, 31-36.

Cazzamali, G., Hauser, F., Kobberup, S., Williamson, M., Grimmelikhuijzen, C.J.P., 2003. Molecular identification of a Drosophila G protein-coupled receptor specific for crustacean cardioactive peptide. Biochem. Biophys. Res. Commun. 303, 146-152.

Cazzamali, G., Klaerke, D.A., Grimmelikhuijzen, C.J.P., 2005a. A new family of insect tyramine receptors. Biochem. Biophys. Res. Commun. 338, 11891196.

Cazzamali, G., Torp, M., Hauser, F., Williamson, M., Grimmelikhuijzen, C.J.P., 2005b. The Drosophila gene CG9918 codes for a pyrokinin-1 receptor. Biochem. Biophys. Res. Commun. 335, 14-19.

Cheung, C.C., Loi, P.K., Sylwester, A.W., Lee, T.D., Tublitz, N.J., 1992. Primary structure of a cardioactve neuropeptide from the tobacco hawkmoth, Manduca sexta. FEBS Lett. 313, 165-168.

Civelli, O., 2005. GPCR deorphanizations: the novel, the known and the unexpected transmitters. Trends Pharmacol. Sci. 26, 15-19.

Civelli, O., Nothacker, H.-P., Saito, Y., Wang, Z., Lin, S.H., Reinscheid, R.K., 2001. Novel neurotransmitters as natural ligands of orphan $G$ proteincoupled receptors. Trends Neurosci. 24, 230-237.

Coast, G.M., Garside, C.S., 2005. Neuropeptide control of fluid balance in insects. Ann. NY Acad. Sci. 1040, 1-8.

Coast, G.M., Webster, S.G., Schegg, K.M., Tobe, S.S., Schooley, D.A., 2001. The Drosophila melanogaster homologue of an insect calcitonin-like diuretic peptide stimulates V-ATPase activity in fruit fly Malpighian tubules. J. Exp. Biol. 204, 1795-1804.

Colas, J.F., Launay, J.M., Kellermann, O., Rosay, P., Maroteaux, L., 1995. Drosophila 5-HT2 serotonin receptor: coexpression with fushi-tarazu during segmentation. Proc. Natl. Acad. Sci. U.S.A. 92, 5441-5445.

Douzery, E.J.P., Snell, E.A., Bapteste, E., Delsuc, F., Philippe, H., 2004. The timing of eukaryotic evolution: does a relaxed molecular clock reconcile proteins and fossils? Proc. Natl. Acad. Sci. U.S.A. 101, 15386-15391.

Egerod, K., Reynisson, E., Hauser, F., Cazzamali, G., Williamson, M., Grimmelikhuijzen, C.J.P., 2003a. Molecular cloning and functional expression of the first two specific insect myosuppressin receptors. Proc. Natl. Acad. Sci. U.S.A. 100, 9808-9813.

Egerod, K., Reynisson, E., Hauser, F., Williamson, M., Cazzamali, G., Grimmelikhuijzen, C.J.P., 2003b. Molecular identification of the first insect proctolin receptor. Biochem. Biophys. Res. Commun. 306, 437-442.

Elekonich, M.M., Roberts, S.P., 2005. Honey bees as a model for understanding mechanisms of life history transitions. Comp. Biochem. Physiol. A. Mol. Integr. Physiol. 141, 362-371.

Eriksen, K.K., Hauser, F., Schiøtt, M., Pedersen, K.-M., Søndergaard, L., Grimmelikhuijzen, C.J.P., 2000. Molecular cloning, genomic organization, developmental regulation, and a knock out mutant of a novel Leu-rich repeats-containing G protein-coupled receptor (DLGR-2) from Drosophila melanogaster. Genome Res. 10, 924-938.

Feng, G., Hannan, F., Reale, V., Hon, Y.Y., Kousky, C.T., Evans, P.D., Hall, L.M., 1996. Cloning and functional characterization of a novel dopamine receptor from Drosophila melanogaster. J. Neurosci. 16, 3925-3933.

Feng, G., Reale, V., Chatwin, H., Kennedy, K., Venard, R., Ericsson, C., Yu, K., Evans, P.D., Hall, L.M., 2003. Functional characterization of a neuropeptide F-like receptor from Drosophila melanogaster. Eur. J. Neurosci. 18, 227 238.
Fraenkel, G., Hsiao, C., 1962. Hormonal and nervous control of tanning in the fly. Science $138,27-29$.

Fraenkel, G., Hsiao, C., Seligman, M., 1966. Properties of bursicon: an insect protein hormone that controls cuticular tanning. Science 151, 91-93.

Gäde, G., Hoffmann, K.H., Spring, J.H., 1997. Hormonal regulation in insects: facts, gaps, and future directions. Physiol. Rev. 77, 963-1032.

Gammie, S.C., Truman, J.W., 1999. Eclosion hormone provides a link between ecdysis-triggering hormone and crustacean cardioactive peptide in the neuroendocrine cascade that controls ecdysis behavior. J. Exp. Biol. 202, 343-352.

Garczynski, S.F., Brown, M.R., Shen, P., Murray, T.F., Crim, J.W., 2002. Characterization of a functional neuropeptide F receptor from Drosophila melanogaster. Peptides 23, 773-780.

Gether, U., 2000. Uncovering molecular mechanisms involved in activation of G protein-coupled receptors. Endocr. Rev. 21, 90-113.

Gotzes, F., Balfanz, S., Baumann, A., 1994. Primary structure and functional characterization of a Drosophila dopamine receptor with high homology to human D1/5 receptors. Receptor Channels 2, 131-141.

Grohmann, L., Blenau, W., Erber, J., Ebert, P.R., Strunker, T., Baumann, A., 2003. Molecular and functional characterization of an octopamine receptor from honey bee (Apis mellifera) brain. J. Neurochem. 86, 725-735.

Han, K.-A., Millar, N.S., Grotewiel, M.S., Davis, R.L., 1996. DAMB, a novel dopamine receptor expressed specifically in Drosophila mushroom bodies. Neuron 16, 1127-1135.

Han, K.-A., Millar, N.S., Davis, R.L., 1998. A novel octopamine receptor with preferential expression in Drosophila mushroom bodies. J. Neurosci. 18, 3650-3658.

Hauser, F., Nothacker, H.-P., Grimmelikhuijzen, C.J.P., 1997. Molecular cloning, genomic organization and developmental regulation of a novel receptor from Drosophila melanogaster structurally related to members of the thyroid-stimulating hormone, follicle-stimulating hormone, luteinizing hormone/choriogonadotropin receptor family from mammals. J. Biol. Chem. $272,1002-1010$.

Hauser, F., Søndergaard, L., Grimmelikhuijzen, C.J.P., 1998. Molecular cloning, genomic organization and developmental regulation of a novel receptor from Drosophila melanogaster structurally related to gonadotropin-releasing hormone receptors from vertebrates. Biochem. Biophys. Res. Commun. 249, 822-828.

Hauser, F., Williamson, M., Cazzamali, G., Grimmelikhuijzen, C.J.P., 2006. Identifying neuropeptide and protein hormone receptors in Drosophila melanogaster by exploiting genomic data. Brief. Funct. Genomics Proteomics 4, 321-330.

Hayes, T.K., Pannabecker, T.L., Hinckley, D.J., Holman, G.M., Nachman, R.J., Petzel, D.H., Beyenbach, K.W., 1989. Leucokinins, a new family of ion transport stimulators and inhibitors in insect Malpighian tubules. Life Sci. 44, 1259-1266.

Hearn, M.G., Ren, Y., McBride, E.W., Reveillaud, I., Beinborn, M., Kopin, A.S., 2002. A Drosophila dopamine 2-like receptor: molecular characterization and identification of multiple alternatively spliced variants. Proc. Natl. Acad. Sci. U.S.A. 99, 14554-14559.

Hewes, R.S., Taghert, P.H., 2001. Neuropeptides and neuropeptide receptors in the Drosophila melanogaster genome. Genome Res. 11, 1126-1142.

Holman, G.M., Cook, B.J., Nachman, R.J., 1986. Isolation, primary structure, and synthesis of leucomyosuppressin, an insect neuropeptide that inhibits spontaneous contractions of the cockroach hindgut. Comp. Biochem. Physiol. C 85, 329-333.

Holt, R.A., Subramanian, G.M., Halpern, A., Sutton, G.G., Charlab, R., Nusskern, D.R., Wincker, P., Clark, A.G., Ribeiro, J.M.C., Wides, R., et al., 2002. The genome sequence of the malaria mosquito Anopheles gambiae. Science 298, 129-149.

Humphries, M.A., Mustard, J.A., Hunter, S.J., Mercer, A., Ward, V., Ebert, P.R., 2003. Invertebrate D2 type dopamine receptor exhibits age-based plasticity of expression in the mushroom bodies of the honeybee brain. J. Neurobiol. 55, 315-330.

Hyun, S., Lee, Y., Hong, S.-T., Bang, S., Paik, D., Kang, J., Shin, J., Lee, J., Jeon, K., Hwang, S., Bae, E., Kim, J., 2005. Drosophila GPCR Han is a receptor for the circadian clock neuropeptide PDF. Neuron 48, $267-$ 278 
Iversen, A., Cazzamali, G., Williamson, M., Hauser, F., Grimmelikhuijzen, C.J.P., 2002a. Molecular cloning and functional expression of a Drosophila receptor for the neuropeptides capa-1 and -2 . Biochem. Biophys. Res. Commun. 299, 628-633.

Iversen, A., Cazzamali, G., Williamson, M., Hauser, F., Grimmelikhuijzen, C.J.P., 2002b. Molecular identification of the first insect ecdysis triggering hormone receptors. Biochem. Biophys. Res. Commun. 299, 924-931.

Johnson, E.C., Bohn, L.M., Barak, L.S., Birse, R.T., Nässel, D.R., Caron, M.G., Taghert, P.H., 2003a. Identification of Drosophila neuropeptide receptors by $\mathrm{G}$ protein-coupled receptors-beta-arrestin2 interactions. J. Biol. Chem. 278, 52172-52178.

Johnson, E.C., Garczynski, S.F., Park, D., Crim, J.W., Nässel, D.R., Taghert, P.H., 2003b. Identification and characterization of a $\mathrm{G}$ protein-coupled receptor for the neuropeptide proctolin in Drosophila melanogaster. Proc. Natl. Acad. Sci. U.S.A. 100, 6198-6203.

Johnson, E.C., Bohn, L.M., Taghert, P.H., 2004. Drosophila CG8422 encodes a functional diuretic hormone receptor. J. Exp. Biol. 207, 743-748.

Johnson, E.C., Shafer, O.T., Trigg, J.S., Park, J., Schooley, D.A., Dow, J.A., Taghert, P.H., 2005. A novel diuretic hormone receptor in Drosophila: evidence for conservation of CGRP signalling. J. Exp. Biol. 208, 12391246.

Jørgensen, L.M., Hauser, F., Cazzamali, G., Williamson, M., Grimmelikhuijzen, C.J.P., 2006. Molecular identification of the first SIFamide receptor. Biochem. Biophys. Res. Commun. 340, 696-701.

Kimura, K., Kodama, A., Hayasaka, Y., Ohta, T., 2004. Activation of the cAMP/ PKA signaling pathway is required for post-ecdysial cell death in wing epidermal cells of Drosophila melanogaster. Development 131, 1597-1606.

Kramer, S.J., Toschi, A., Miller, C.A., Kataoka, H., Quistad, G.B., Li, J.P., Carney, R.L., Schooley, D.A., 1991. Identification of an allatostatin from the tobacco hornworm Manduca sexta. Proc. Natl. Acad. Sci. U.S.A. 88, 94589462.

Kreienkamp, H.J., Larusson, H.J., Witte, I., Roeder, T., Birgul, N., Honck, H.H., Harder, S., Ellinghausen, G., Buck, F., Richter, D., 2002. Functional annotation of two orphan G protein-coupled receptors, Drostar1 and -2 , from Drosophila melanogaster and their ligands by reverse pharmacology. J. Biol. Chem. 277, 39937-39943.

Kubiak, T.M., Larsen, M.J., Burton, K.J., Bannow, C.A., Martin, R.A., Zantello, M.R., Lowery, D.E., 2002. Cloning and functional expression of the first Drosophila melanogaster sulfakinin receptor DSK-R1. Biochem. Biophys. Res. Commun. 291, 313-320.

Kula, E., Levitan, E.S., Pyza, E., Rosbash, M., 2006. PDF cycling in the dorsal protocerebrum of the Drosophila brain is not necessary for circadian clock function. J. Biol. Rhythms 21, 104-117.

Larsen, M.J., Burton, K.J., Zantello, M.R., Smith, V.G., Lowery, D.L., Kubiak, T.M., 2001. Type A allatostatins from Drosophila melanogaster and Diploptera punctata activate two Drosophila allatostatin receptors, DAR-1 and DAR-2, expressed in CHO cells. Biochem. Biophys. Res. Commun. 286, 895-901.

Lear, B.C., Merrill, C.E., Lin, J.-M., Schroeder, A., Zhang, L., Allada, R., 2005. A G protein-coupled receptor, groom-of- $P D F$, is required for PDF neuron action in circadian behavior. Neuron 48, 221-227.

Lee, K.S., You, K.H., Choo, J.K., Han, Y.M., Yu, K., 2004. Drosophila short neuropeptide F regulates food intake and body size. J. Biol. Chem. 279, 50781-50789.

Lenz, C., Williamson, M., Grimmelikhuijzen, C.J.P., 2000a. Molecular cloning and genomic organization of an allatostatin preprohormone from Drosophila melanogaster. Biochem. Biophys. Res. Commun. 273, 1126-1131.

Lenz, C., Søndergaard, L., Grimmelikhuijzen, C.J.P., 2000b. Molecular cloning and genomic organization of a novel receptor from Drosophila melanogaster structurally related to mammalian galanin receptors. Biochem. Biophys. Res. Commun. 269, 91-96.

Lenz, C., Williamson, M., Hansen, G.N., Grimmelikhuijzen, C.J.P., 2001. Identification of four Drosophila allatostatins as the cognate ligands for the Drosophila orphan receptor DAR-2. Biochem. Biophys. Res. Commun. 286, 1117-1122.

Li, X.-J., Wolfgang, W., Wu, Y.-N., North, R.A., Forte, M., 1991a. Cloning, heterologous expression and developmental regulation of a Drosophila receptor for tachykinin-like peptides. EMBO J. 10, 3221-3229.
Li, X.-J., Wu, Y.-N., North, R.A., Forte, M., 1991b. Cloning, functional expression and developmental regulation of a neuropeptide $\mathrm{Y}$ receptor from Drosophila melanogaster. J. Biol. Chem. 267, 9-12.

Lorenz, M.W., Kellner, R., Hoffmann, K.H., 1995. A family of neuropeptides that inhibit juvenile-hormone biosynthesis in the cricket Gryllus bimaculatus. J. Biol. Chem. 270, 21103-21108.

Luo, C.W., Dewey, E.M., Sudo, S., Ewer, J., Hsu, S.Y., Honegger, H.W., Hsueh, A.J., 2005. Bursicon, the insect cuticle-hardening hormone, is a heterodimeric cystine knot protein that activates $G$ protein-coupled receptor LGR2. Proc. Nat1. Acad. Sci. U.S.A. 102, 2820-2825.

Maqueira, B., Charwin, H., Evans, P.D., 2005. Identification and characterization of a novel family of Drosophila $\beta$-adrenergic-like octopamine G protein-coupled receptors. J. Neurochem. 94, 547-560.

Meeusen, T., Mertens, I., Clynen, E., Baggerman, G., Nichols, R., Nachman, R.J., Huybrechts, R., De Loof, A., Schoofs, L., 2002. Identification in Drosophila melanogaster of the invertebrate G protein-coupled FMRFamide receptor. Proc. Natl. Acad. Sci. U.S.A. 99, 15363-15368.

Mendive, F.M., Van Loy, T., Claeysen, S., Poels, J., Williamson, M., Hauser, F., Grimmelikhuijzen, C.J.P., Vassart, G., Vanden Broeck, J., 2005 Drosophila molting neurohormone bursicon is a heterodimer and the natural agonist of the orphan receptor DLGR2. FEBS Lett. 579, 21712176.

Mertens, I., Meeusen, T., Huybrechts, R., De Loof, A., Schoofs, L., 2002. Characterization of the short neuropeptide F receptor from Drosophila melanogaster. Biochem. Biophys. Res. Commun. 297, 1140-1148.

Mertens, I., Vandingenen, A., Johnson, E.C., Shafer, O.T., Li, W., Trigg, J.S., De Loof, A., Schoofs, L., Taghert, P.H., 2005. PDF receptor signalling in Drosophila contributes to both circadian and geotactic behaviors. Neuron 48, 213-219.

Monnier, D., Colas, J.F., Rosay, P., Hen, R., Borrelli, E., Maroteaux, L., 1992. NKD, a developmentally regulated tachykinin receptor in Drosophila. J. Biol. Chem. 267, 1298-1302.

Mustard, J.A., Blenau, W., Hamilton, I.S., Ward, V.K., Ebert, P.R., Mercer, A.R., 2003. Analysis of two D1-like dopamine receptors from the honey bee Apis mellifera reveals agonist-independent activity. Brain Res. Mol. Brain Res. 113, 67-77.

Nichols, R., 2003. Signaling pathways and physiological functions of Drosophila melanogaster FMRFamide-related peptides. Ann. Rev. Entomol. 48, 485-503.

Nässel, D.R., 2002. Neuropeptides in the nervous system of Drosophila and other insects: multiple roles as neuromodulators and neurohormones. Prog. Neurobiol. 68, 1-84.

Onai, T., Fitzgerald, M.G., Arakawa, S., Gocayne, J.D., Urquhart, D.A., Hall, L.M., Fraser, C.M., McCombie, W.R., Venter, J.C., 1989. Cloning, sequence analysis and chromosome localization of a Drosophila muscarinic acetylcholine receptor. FEBS Lett. 255, 219-225.

Paluzzi, J.P., Orchard, I., 2006. Distribution, activity and evidence for the release of an anti-diuretic peptide in the kissing bug Rhodnius prolixus. J. Exp. Biol. 209, 907-915.

Park, Y., Kim, Y.J., Adams, M.E., 2002. Identification of G protein-coupled receptors for Drosophila PRXamide peptides, CCAP, corazonin, and AKH supports a theory of ligand-receptor coevolution. Proc. Natl. Acad. Sci. U.S.A. 99, 11423-11428.

Park, Y., Kim, Y.J., Dupriez, V., Adams, M.E., 2003. Two subtypes of ecdysistriggering hormone receptor in Drosophila melanogaster. J. Biol. Chem. 278, 17710-17715.

Pollock, V.P., McGettigan, J., Cabrero, P., Maudlin, I.M., Dow, J.A., Davies, S.A., 2004. Conservation of capa peptide-induced nitric oxide signalling in Diptera. J. Exp. Biol. 207, 4135-4145.

Radford, J.C., Davies, S.A., Dow, J.A., 2002. Systematic G protein-coupled receptor analysis in Drosophila melanogaster identifies a leucokinin receptor with novel roles. J. Biol. Chem. 277, 38810-38817.

Rao, K.R., Mohrherr, C.J., Riehm, J.P., Zahnow, C.A., Norton, S., Johnson, L., Tarr, G.E., 1987. Primary structure of an analog of crustacean pigmentdispersing hormone from the lubber grasshopper Romalea microptera. J. Biol. Chem. 262, 2672-2675.

Renn, S.C., Park, J.H., Rosbash, M., Hall, J.C., Taghert, P.H., 1999. A PDF neuropeptide gene mutation and ablation of PDF neurons each cause severe 
abnormalities of behavioral circadian rhythms in Drosophila. Cell 99, 791802.

Riehm, J.P., Rao, K.R., 1982. Structure-activity relationships of a pigmentdispersing crustacean neurohormone. Peptides 3, 643-647.

Roeder, T., 2003. Metabotropic histamine receptors-nothing for invertebrates? Eur. J. Pharmacol. 466, 85-90.

Roeder, T., 2005. Tyramine and octopamine: ruling behavior and metabolism. Annu. Rev. Entomol. 50, 447-477.

Rosenkilde, C., Cazzamali, G., Williamson, M., Hauser, F., Søndergaard, L., DeLotto, R., Grimmelikhuijzen, C.J.P., 2003. Molecular cloning, functional expression, and gene silencing of two Drosophila receptors for the Drosophila neuropeptide pyrokinin-2. Biochem. Biophys. Res. Commun. 309, 485-494.

Saudou, F., Amlaiky, N., Plassat, J.L., Borrelli, E., Hen, R., 1990. Cloning and characterization of a Drosophila tyramine receptor. EMBO J. 9, 3611-3617.

Saudou, F., Boschert, U., Amlaiky, N., Plassat, J.L., Hen, R., 1992. A family of Drosophila serotonin receptors with distinct intracellular signalling properties and expression patterns. EMBO J. 11, 7-17.

Savard, J., Tautz, D., Richards, S., Weinstock, G.M., Gibbs, R.A., Werren, J.H., Tettelin, H., Lercher, M.J., 2006. Phylogenomic analysis reveals bees and wasps (Hymenoptera) at the base of the radiation of holometabolous insects. Genome Res., in press.

Schlenstedt, J., Balfanz, S., Baumann, A., Blenau, W., 2006. Am${ }_{5}-\mathrm{HT}_{7}$ : molecular and pharmacological characterization of the first serotonin receptor of the honeybee (Apis mellifera). J. Neurochem. 98, 1985-1988.

Schoofs, L., Holman, G.M., Hayes, T.K., Nachman, R.J., De Loof, A., 1991. Isolation, identification and synthesis of locustamyoinhibiting peptide (LOM-MIP), a novel biologically active neuropeptide from Locusta migratoria. Regul. Pept. 36, 111-119.

Secher, T., Lenz, C., Cazzamali, G., Sørensen, G., Williamson, M., Hansen, G.N., Svane, P., Grimmelikhuijzen, C.J.P., 2001. Molecular cloning of a functional allatostatin gut/brain receptor and an allatostatin preprohormone from the silkworm Bombyx mori. J. Biol. Chem. 276, 47052-47060.

Shapiro, R.A., Wakimoto, B.T., Subers, E.M., Nathanson, N.M., 1989. Characterization and functional expression in mammalian cells of genomic and cDNA clones encoding a Drosophila muscarinic acetylcholine receptor. Proc. Natl. Acad. Sci. U.S.A. 86, 9039-9043.

Srivastava, D.P., Yu, E.J., Kennedy, K., Chatwin, H., Reale, V., Hamon, M., Smith, T., Evans, P.D., 2005. Rapid, nongenomic responses to ecdysteroids and catecholamines mediated by a novel Drosophila G protein-coupled receptor. J. Neurosci. 25, 6145-6155.

Stables, J., Green, A., Marshall, F., Fraser, N., Knight, E., Sautel, M., Milligan, G., Lee, M., Rees, S., 1997. A bioluminescent assay for agonist activity at potentially any G protein-coupled receptor. Anal. Biochem. 252, 115-126.

Staubli, F., Jørgensen, T.J.D., Cazzamali, G., Williamson, M., Lenz, C., Søndergaard, L., Roepstorff, P., Grimmelikhuijzen, C.J.P., 2002. Molecular identification of the insect adipokinetic hormone receptors. Proc. Natl. Acad. Sci. U.S.A. 99, 3446-3451.

Sudo, S., Kuwabara, Y., Park, J.I., Hsu, S.Y., Hsueh, A.J., 2005. Heterodimeric fly glycoprotein hormone-alpha2 (GPA2) and glycoprotein hormone-beta5 (GPB5) activate fly leucine-rich repeat-containing G protein-coupled receptor-1 (DLGR1) and stimulation of human thyrotropin receptors by chimeric fly GPA2 and human GPB5. Endocrinology 146, 3596-3604.

Sugamori, K.S., Demchyshyn, L.L., McConkey, F., Forte, M.A., Niznik, H.B., 1995. A primordial dopamine D1-like adenylyl cyclase-linked receptor from Drosophila melanogaster displaying poor affinity for benzazepines. FEBS Lett. 362, 131-138.
Tawfik, A.I., Tanaka, S., De Loof, A., Schoofs, L., Baggerman, G., Waelkens, E., Derua, R., Milner, Y., Yerushalmi, Y., Pener, M.P., 1999. Identification of the gregarization-associated dark-pigmentotropin in locusts through an albino mutant. Proc. Natl. Acad. Sci. U.S.A. 96, 7083-7087.

The Honey Bee Genome Sequencing Consortium, 2006. Insights into social insects from the genome of the honey bee Apis mellifera. Nature, in press.

Vanden Broeck, J., 2001. Neuropeptides and their precursors in the fruitfly, Drosophila melanogaster. Peptides 22, 241-254.

Veenstra, J.A., 1989. Isolation and structure of corazonin, a cardioactive peptide from the American cockroach. FEBS Lett. 250, 231-234.

Verleyen, P., Clynen, E., Huybrechts, J., Van Lommel, A., Vanden Bosch, L., De Loof, A., Zdarek, J., Schoofs, L., 2004a. Fraenkel's pupariation factor identified at last. Dev. Biol. 273, 38-47.

Verleyen, P., Huybrechts, J., Baggerman, G., Van Lommel, A., De Loof, A., Schoofs, L., 2004b. SIFamide is a highly conserved neuropeptide: a comparative study in different insect species. Biochem. Biophys. Res. Commun. 320, 334-341.

Verleyen, P., Baggerman, G., Mertens, I., Vandersmissen, T., Huybrechts, J., Van Lommel, A., De Loof, A., Schoofs, L., 2006. Cloning and characterization of a third isoform of corazonin in the honey bee Apis mellifera. Peptides 27, 493-499.

von Frisch, K., 1994. The "language" of bees and its utilization in agriculture. Experientia 50, 406-413.

Wegener, C., Herbert, Z., Eckert, M., Predel, R., 2002. The periviscerokinin (PVK) peptide family in insects: evidence for the inclusion of CAP (2b) as a PVK family member. Peptides 23, 605-611.

Wei, Z., Baggerman, G., Nachman, R., Goldsworthy, G., Verhaert, P., De Loof, A., Schoofs, L., 2000. Sulfakinins reduce food intake in the desert locust, Schistocerca gregaria. J. Insect Physiol. 46, 1259-1265.

Williamson, M., Lenz, C., Winther, Å.M.E., Nässel, D.R., Grimmelikhuijzen, C.J.P., 2001a. Molecular cloning, genomic organization, and expression of a B-type (cricket-type) allatostatin preprohormone from Drosophila melanogaster. Biochem. Biophys. Res. Commun. 281, 544-550.

Williamson, M., Lenz, C., Winther, Å.M.E., Nässel, D.R., Grimmelikhuijzen, C.J.P., 2001b. Molecular cloning, genomic organization, and expression of a C-type (Manduca sexta-type) allatostatin preprohormone from Drosophila melanogaster. Biochem. Biophys. Res. Commun. 282, 124-130.

Witz, P., Amlaiky, N., Plassat, J.L., Maroteaux, L., Borrelli, E., Hen, R., 1990. Cloning and characterization of a Drosophila serotonin receptor that activates adenylate cyclase. Proc. Natl. Acad. Sci. U.S.A. 87, 8940-8944.

Woodhead, A.P., Stay, B., Seidel, S.L., Khan, M.A., Tobe, S.S., 1989. Primary structure of four allatostatins: neuropeptide inhibitors of juvenile hormone synthesis. Proc. Natl. Acad. Sci. U.S.A. 86, 5997-6001.

Wu, Q., Zhao, Z., Shen, P., 2005. Regulation of aversion to noxious food by Drosophila neuropeptide Y- and insulin-like systems. Nat. Neurosci. 8, 1350-1355.

Xia, Q., Zhou, Z., Lu, C., Cheng, D., Dai, F., Li, B., Zhao, P., Zha, X., Cheng, T., Chai, C., et al., 2004. A draft sequence for the genome of the domesticated silkworm (Bombyx mori). Science 306, 1937-1940.

Yamanaka, N., Hua, Y.J., Mizoguchi, A., Watanabe, K., Niwa, R., Tanaka, Y., Kataoka, H., 2005. Identification of a novel prothoracicostatic hormone and its receptor in the silkworm Bombyx mori. J. Biol. Chem. 280, 1468414690.

Zitnan, D., Kingan, T.G., Hermesman, J.L., Adams, M.E., 1996. Identification of ecdysis-triggering hormone from an epitracheal endocrine system. Science 271, 88-91. 